Molnár Anna - Molnár Éva - Takács Lili - Vecsey Mariann

\title{
A nemzetközi jelenlét Líbiában 2011-töl napjainkig
}

\begin{abstract}
Tanulmányunkban a nagyhatalmak (Egyesült Államok, Oroszország és Kína), az európai vezető hatalmak (Franciaország, Olaszország, Németország) és a regionális szereplők (Egyiptom, Szaúd-Arábia, Katar, Egyesült Arab Emírségek és Törökország) szerint csoportokra bontva, az emlitett államok líbiai szerepvállalásának legjellemzőbb vonásait foglaljuk össze, megjelenitve az adott állam által használt puha és/vagy kemény külpolitikai eszközöket is. Khalífa Haftar Tripoli ellen indított 2019. áprilisi offenzívája tovább bonyolítja a líbiai belpolitikai helyzetet, így a külföldi szereplők befolyása és líbiai kapcsolatrendszere is várhatóan komplexebb lesz. A vizsgált államok líbiai érdekei azonban alapjaiban nem fognak változni, így ha az általuk használt külpolitikai eszközökben változás következik be, az a kemény eszközök irányába történó elmozdulás lesz/lehet, ami spirálszerüen tovább nehezitheti Libia stabilizálását.
\end{abstract}

Kulcsszavak: Líbia, Khalífa Haftar, nagyhatalmak, Olaszország, Franciaország

\section{Molnár Anna - Molnár Éva - Takács Lili - Vecsey Mariann: International Presence in Libya from 2011}

Great powers (the United States, Russia, China), European leading powers (France, Italy, Germany) and regional powers (Egypt, Saudi Arabia, the United Arab Emirates, Turkey) have been using different hard and soft foreign policy tools in the civil war-torn Libya in order to pursue their own interests. The ongoing offensive launched by Khalifa Haftar in April 2019 complicates further the Libyan political landscape; it will also affect the influence and relations within Libya of the above mentioned powers. Their interests remain unchanged; however, the foreign policy tools used by the international actors can harden, which compounds further the stabilisation of Libya.

Keywords: Libya, Khalifa Haftar, great powers, Italy, France

\section{Bevezetés}

2011 februárja, vagyis az arab tavasz líbiai tüntetéseinek kezdete óta az országot instabilitás jellemzi. Miután a Kaddáfi-rendszer elleni tüntetéseket a hatalom brutális kegyetlenséggel igyekezett leverni, a nyugati hatalmak a beavatkozás mellett döntöttek. A nemzetközi közösség élesen elítélte a békés tüntetők elleni véres fellépést, és Kaddáfival szemben kemény büntetésről határozott (ENSZ BT 1973. sz. határozat). Franciaország vezetésével, valamint elsősorban az Egyesült Államok és az Egyesült Királyság támogatásával megkezdődött az Odyssey Dawn (Hajnali Odüsszeia) művelet. Olaszország ekkor még közvetlenül nem vett részt a bombázásokban, elsősorban logisztikai infrastruktúrát és katonai bázisait bocsátotta a koalíciós erők rendelkezésére. A NATO-tagállamok megállapodását követően a szervezet vezette a beavatkozást (Operation Unified Protector), amelyet nem kö- 
vetett megfelelö demokrácia- és államépítési folyamat, így az ország folyamatosan mélyülö káoszba süllyedt.

A nemzetközi közösség körülbelül egy évszázaddal Olaszország líbiai gyarmatosító hadjárata után ugyanazzal a problémával küzdött, mint a gyarmatosító olaszok. A második világháború után, az ENSZ által mesterségesen létrehozott mai Líbia ugyanis nem tekinthető egységes földrajzi, politikai, gazdasági entitásnak, az állam létrejötte ellenére nem alakult ki Kaddáfi bukását követően is fenntartható és müködőképes központi politikai intézményrendszer. A törzsi struktúrák dominálta országban a törzsi, és szűkebb regionális szintű identitások, illetve a velük kapcsolatban megmutatkozó lojalitás ma is erősebb a nemzeti identitásnál vagy az állam iránti lojalitásnál. A kifelé egységesnek mutatkozó állam felszíne alatt a belső megosztottság mindig fennmaradt.

Noha 2011 és 2014 között az Általános Nemzeti Kongresszus (General National Congress - GNC) még többé-kevésbé gyakorolta a központi hatalmat, ezt követően nem maradt olyan föhatalom, amelynek az ország egész területe felett hatalma lenne. Az ország - a létrejötte elötti időszakhoz hasonlóan - gyakorlatilag három részre szakadt: Tripolitánia (az ország nyugati része), Kirenaika (az ország keleti része) és Fezzán (déli területek) szinte külön-külön entitások lettek. A keleti és nyugati országrész különböző csoportjai egymással harcolnak a hatalomért, amióta azonban nemzetközi szereplők is elkezdték támogatni a feleket, Líbia belső konfliktusa nemzetköziesedett, és ez a 2019 áprilisában újraindult harcokban még egyértelmübbé vált. ${ }^{1}$

Tanulmányunkban a nagyhatalmak (Egyesült Államok, Oroszország és Kína), az európai vezető hatalmak (Franciaország, Olaszország és Németország), illetve a regionális szereplők (Egyiptom, Szaúd-Arábia, Katar, az Egyesült Arab Emírségek és Törökország) szerint csoportokra bontva, az említett államok líbiai szerepvállalásának legjellemzőbb vonásait foglaljuk össze, megjelenítve az adott állam által használt puha (soft) és/vagy kemény (hard) külpolitikai eszközöket is. ${ }^{2}$ Kemény külpolitikai eszköznek elsősorban a katonai jelenlétet tekintjük, beleértve a katonai tanácsadók és a különleges erők fellépését is. A gazdasági szankciókon keresztül történő érdekérvényesítést is idesoroljuk, míg a segélyezést a puha eszközök közé. Amellett, hogy figyelembe vesszük, hogy a kemény és puha külpolitikai eszközök alkalmazása párhuzamosan folyik - hiszen ezek az eszközök nem egymás alternatívái, hanem kiegészítik egymást, egyik sem létezhet hatékonyan a másik

\footnotetext{
A líbiai helyzetről lásd: Tálas Péter et al: A líbiai beavatkozás motivációi és nemzetközi megítélése, [online], Nemzet és Biztonság, 4. évf., 2011/3, 65-84. o.; MARsAi Viktor: A líbiai válság elmúlt két és fél éve európai szemszögből, [online], Nemzet és Biztonság, 7. évf., 2014/3, 82-104. o.; MARsAi Viktor: A migrációs diskurzus margójára III. - A líbiai válság az európai migráció tükrében, [online], Nemzet és Biztonság, 10. évf., 2017/1, 110-131. o.; MARsai Viktor: Líbia agóniája. In: Molnár Anna - Komlósi Orsolya (szerk.): Az Európai Unió mediterrán térséggel összefüggő kapcsolata. Párbeszéd és konfliktusok, [online], Dialóg Campus Kiadó, Budapest, 2019, 77-94. o.

A „puha hatalom” (soft power) fogalma az 1990-es évek elején jelent meg a nemzetközi politikai gondolkodásban. Megalkotója Joseph Nye amerikai professzor volt. A kifejezés azt jelenti, hogy egy ország mennyire képes nem katonai eszközökkel érvényesíteni gazdasági, politikai érdekeit. A puha eszközök használatával ország képes lehet arra, hogy kényszer vagy fizetség nélkül - a vonzás hatalmával - érje el azt, hogy más országok ugyanazt akarják, amit ő akar, tehát azokon a tényezőkön alapszik, amelyek az adott államot vonzóvá, mások szemében követendő példává tudják tenni. A hard power ezzel ellentétben a kényszerítő erő alkalmazásán vagy közvetlen ellenszolgáltatás megfizetésén alapszik. Joseph Nye a soft power forrásának a kultúrát, politikai értékeket és eszméket, valamint kül- és belpolitikát tartotta. Lásd: NYE, Joseph S.: Soft Power: The Means To Success In World Politics, PublicAffairs, New York, 2004.
} 
nélkül -, a tanulmányban az egyes országoknál az érdekérvényesítést meghatározó külpolitikai eszközét jelenítjük meg.

Terjedelmi okok miatt jelen tanulmány nem terjed ki az Európai Unió és a hagyományos nemzetközi szervezetek szerepének vizsgálatára. Ezen aktorok szerepének vizsgálatát egy következő tanulmány keretein belül tervezzük bemutatni.

\section{Nagyhatalmak}

\section{Egyesült Államok - a már háttérböl sem vezetö ${ }^{3}$}

Az Egyesült Államok 2011-ben az 1973. sz. BT határozat megszavazása után légierejével aktívan részt vett a Kaddáfi-rezsim megbuktatásában. Kaddáfi halála után az Obamaadminisztráció még sikeresnek ítélte a beavatkozást, hiszen támogatást nyújtott az arab tavasz felemelkedő mozgalmainak, sikerült elkerülni egy költséges, és amerikai áldozatokkal járó szárazföldi beavatkozást. Úgy tűnt, Líbia megszűnik potenciális terrorista országnak lenni. Visszatekintve azonban már maga Barack Obama is kudarcként értékelte a beavatkozást, ${ }^{4}$ hiszen Líbia nemhogy nem vált demokráciává, de az állam müködőképessége is megkérdőjeleződött, gyakorlatilag bukott állammá vált.

Az Egyesült Államok Líbia-politikáját öt szakaszra oszthatjuk az arab tavasz kezdetétől napjainkig. Eleinte - 2011 februárja és októbere között - alapvető szerepet játszott a líbiai tüntetések támogatásában és a rezsim katonai beavatkozással támogatott megdöntésében, majd Kaddáfi halála után, a NATO-beavatkozás végén kezdődött a második szakasz, amikor az Egyesült Államok helyreállította a diplomáciai jelenlétét Líbiában, és támogatta az átmeneti hatóságokat. Ez a szakasz Chris Stevens nagykövet meggyilkolásával ért véget. ${ }^{5}$ A harmadik szakasz 2012 szeptemberétöl 2014 júliusáig tartott, ezt leginkább a Stevensgyilkosság sokkja határozta meg, a szakasz végét pedig a tripoli amerikai nagykövetség polgárháborús erőszak miatti evakuálása jelenti. 2014 júliusától 2017 januárjáig az Egyesült Államok támogatta az ENSZ líbiai stabilizációs törekvéseit, majd a Líbiai Politikai Megállapodás (Libyan Political Agreement) alapján felálló egységkormányt (Gorvernment of National Accord - GNA). Ehhez az időszakhoz köthetők a mintegy hat hónapig tartó légicsapások is a Szirt környéki ISIS-állások ellen. Az ötödik, napjainkig tartó szakasz 2017 januárjában kezdődött, amelyet a Líbiától való szinte teljes elfordulás jellemez, a terrorellenes fellépéstől eltekintve. ${ }^{6}$ A kemény eszközök használata legerősebben az első, és a második szakaszban, valamint az úgynevezett „Iszlám Állam” elleni légicsapások során volt jellemző, ezeken kívül inkább a puha eszközök használata dominált.

A Trump-adminisztráció előtt két lehetőség állt: vagy a Líbiából való teljes kivonulás, a többi nemzetközi szereplöre hagyva a rendezést, vagy pedig a líbiai szerepvállalás erősí-

\footnotetext{
Barack Obama a líbiai beavatkozás kapcsán az Egyesült Államok politikáját a „leading from behind”, azaz háttérből vezető kifejezéssel foglalta össze.

4 Dominic Tierney: The Legacy of Obama’s 'Worst Mistake', [online], 2016. 04. 15. Forrás: theatlantic.com [2019. 03. 09.] Chris Stevens amerikai nagykövetet 2012. szeptember 11-én, a bengázi külképviselet elleni támadás során gyilkolták meg.

6 Ben Fishman: United States: Reluctant Engagement. In: Karim Mezran - Arturo Varvelli (eds.): Foreign Actors in Libya’s Crisis, Atlantic Council, Edizione LediPublishing, Milano, 2017, 92. o.
} 
tése, a stabilizációban való aktív részvétel felvállalásával. Kampányszlogenének megfelelöen, beiktatása után Donald Trump az „Amerika az első” elképzelés alapján távolságot tartott azoktól a tengerentúli konfliktusoktól, amelyek nem érintik közvetlenül az Egyesült Államok biztonsági érdekeit. Ez a megközelítés Líbia esetében is megmutatkozott. A líbiai válságtól való elfordulást mutatja, hogy Trump nem nevezett ki líbiai különmegbízottat, ${ }^{7}$ 2017 végétől 2018 novemberéig Washington nem delegált nagykövetet Líbiába, s hogy Líbia a kezdetektől fogva szerepelt Trump beutazástilalmi listáján, amely megtiltotta a líbiai állampolgároknak az Egyesült Államokba való belépést. ${ }^{8}$

A legláthatóbb amerikai szerepvállalás elsődlegesen az úgynevezett „Iszlám Állam” líbiai állásainak bombázásában és a Chris Stevens amerikai nagykövet meggyilkolásáért felelős személyek felderítésében és elfogásában ${ }^{9}$ merült ki, ezenkívül azonban Donald Trump nem kívánt aktív szerepet betölteni Líbia stabilizálásában, ahogy ezt Paolo Gentiloni olasz miniszterelnök washingtoni látogatása során is bejelentette 2017 áprilisában.

A korlátozott amerikai szerepvállalást mutatja, hogy az Egyesült Államok nem törekedett a dinamikusan változó líbiai hatalmi központokkal való kapcsolatfelvételre, továbbra is az ENSZ által létrehozott egységkormány mellett állt ki, annak ellenére, hogy a többi nemzetközi szereplő már diverzifikált érdekképviseletet folytatott Líbiában. A líbiai válságtól való amerikai távolmaradást jól mutatja, hogy Mike Pompeo külügyminiszter 2018. december 4-én tweetelt elöször Líbiáról, azonban ez is csak a nemzetközi közösség által támogatott GNA vezetőjével, Fájez esz-Szarráddzsal való találkozójáról szólt. A Szarrádzs-kormány egyértelmüen élvezi az Egyesült Államok támogatását, a miniszterelnököt gyakran fogadták amerikai hivatalnokok, a keleti országrész legbefolyásosabb szereplőjétől, Haftartól azonban távol tartották magukat, a korábbi - feltételezett - kapcsolataik ellenére. ${ }^{10}$

Úgy tünik azonban, hogy 2018-ban Washington már elkezdte felismerni, milyen következményekkel járhat a Líbiától való elfordulás, és tett néhány kezdetleges lépést a rivalizáló hatalmi csoportokkal való kapcsolata kiegyensúlyozására. 2018 decemberében Haftar római látogatása során találkozott David Rubinsteinnel, az Egyesült Államok tunéziai nagykövetével. ${ }^{11}$ A fehér házi képviselők tettek arra utaló megjegyzéseket is, hogy Washington

Az előző líbiai különmegbízott (Special Envoy to Libya), Jonathan Winer megbízatása véget ért, amikor Obamát Donald Trump váltotta az elnöki székben.

8 Josh Gerstein - Jeremy C. F. Lin: Why these 7 countries are listed on Trump's travel ban, [online], 2018. 06. 26. Forrás: Politico.com, [2019. 02. 13.]; valamint Presidential Proclamation Enhancing Vetting Capabilities and Processes for Detecting Attempted Entry Into the United States by Terrorists or Other Public-Safety Threats, [online], 2017. 09. 24. Forrás: Whitehouse.gov [2019. 03. 09.]

9 Benghazi: US Navy SEALs capture man suspected over fatal attack on diplomatic post in Libya, [online], 2017. 10. 31. Forrás: ABC.net.au [2019. 03. 04.]

10 Haftar a nyolcvanas években, Kaddáfi csádi hadmüveletében fogságba esett, ahonnan amerikai segítséggel szabadult ki 1990-ben. 2011-ig az USA-ban élt, Virginiában, a CIA Központ közelében, amerikai állampolgárságot szerzett, közben Líbiában halálra ítélték a Dzsamáhírijja ellen elkövetett bűneiért. A CIA támogatta a líbiai emigránsok szervezésében, hiszen egy esetleges Kaddáfi-ellenes felkelés vezetőjét látta benne, ez azonban nem járt sikerrel, a kétezres években Líbia nemzetközi rendszerbe való reintegrálódása pedig az említett felkelés tervét háttérbe szorította. Ekkortól kezdve a líbiai dzsihádisták megfékezését bízták Haftarra - ez az erős iszlamistaellenes hangja máig megmaradt. Tény azonban, hogy valamikor a kétezres években Haftar eltávolodott az Egyesült Államoktól és Moszkvához közeledett, ennek okai azonban nyílt forrásokból nem lelhetők fel.

11 Libia, Haftar a Roma per incontrare Conte. L'Italia sempre più vicina al generale, [online], 2018. 12. 05. Forrás: Ilmessaggero.it [2019.03.02.] 
számára elképzelhető, hogy Haftar szerephez jut a jövő Líbiájában. ${ }^{12}$ Amennyiben ez hivatalos állásponttá válik, jelentős fordulat fog bekövetkezni az Egyesült Államok Líbiapolitikájában, és a nemzetközi szereplők által - kisebb-nagyobb - lendülettel szorgalmazott békéltetési folyamatot is fellendítheti.

Időről időre az európai országok és a különböző líbiai frakciók is arra kérik az Egyesült Államokat, hogy vállaljon nagyobb szerepet a konfliktus megoldásában. Egyrészt arra hivatkoznak, hogy az Egyesült Âllamok az egyetlen állam, amely nyomást gyakorolva az európai és az arab államokra, képes a líbiai káosz rendezésére, és az ENSZ líbiai tervének kikényszerítésére. Másrészt pedig arra, hogy a jelenlegi helyzet kialakulásához az Egyesült Államok tevékenyen hozzájárult, amikor hosszú távú stratégia nélkül avatkozott be 2011ben. Amerika líbiai szerepvállalásának vizsgálatakor figyelembe kell vennünk, hogy Washingtonnak nem érdeke még egy fegyveres beavatkozásban részt venni a MENArégióban, hiszen a többi, amerikai részvétellel zajló fegyveres konfliktust vizsgálva - Irak, Szomália, Afganisztán - az látható, hogy hiába áldoztak az amerikai adminisztrációk a komoly politikai tőke mellett dollár milliárdokat a konfliktusok rendezésére, a tartós stabilitást nem tudták elérni, a térségbeli radikalizálódás viszont növekedett. Az az elgondolás pedig, hogy csak az Egyesült Államok rendelkezik akkora hatalmi tőkével, hogy minden felet megegyezésre bírjon, meghaladott. Líbia elhelyezkedése és kőolaja Washington geopolitikájában nem élvez elsődleges fontosságot. Az Egyesült Államok számára Líbia földrajzi pozíciója nem jelentősebb, mint bármelyik másik észak-afrikai országé, a líbiai kőolaj pedig a világ kőolaj-kitermelésének csak kisebb részét képezi, amelyből az USA nagyon keveset importál, ${ }^{13}$ ezek inkább az európai országok számára fontosak, így - Washington szempontjából - európai megoldást igényelnek, nem amerikait. ${ }^{14}$ Líbia egyetlen, amerikai érdekek szempontjából közvetlen relevanciája a radikális iszlamizmusban rejlik, így a terrorizmus elleni globális háborúban Líbiát is figyelembe kell venni, azonban ebben is csak mellékhadszíntérnek tekinthető.

A fentiek alapján az Egyesült Államoknak látszólag nem füződik közvetlen érdeke ahhoz, hogy aktívan részt vegyen a líbiai válságban, amit a jelenlegi adminisztráció lépései is tükröznek. Fontos azonban megjegyezni, hogy korábban Haftar a CIA-val tartott fenn szoros kapcsolatot. Amíg az USA kitart az ENSZ által támogatott akcióterv megvalósítása mellett - annak ellenére, hogy a nemzetközi szereplök többsége már felismerve az ENSZakcióterv korlátait, túllépett rajta -, politikája nem tart lépést a líbiai fejleményekkel. Mindazonáltal amennyiben Líbia terrorizmussal való viszonya megváltozik, rákényszerítheti a Trump-adminisztrációt az aktívabb fellépésre. Ugyanilyen hatást gyakorolhat az amerikai külpolitikára, ha Oroszország növeli líbiai szerepét, akár a fegyverembargó megszegésével. Ebben az esetben ugyanis Trumpnak döntenie kell arról, hogy Líbiát - leg-

12 Malsin, Jared: Libyan Warlord Embraced by Foreign Leaders as a Key to Peace, [online], 2018. 12. 03. Forrás: Wsj.com [2019. 03. 08.]

13 U.S. Energy Information Administration: U.S. Import from Libya of Crude Oil and Petroleum Products, [online]. Forrás: Eia.gov [2019. 03. 07.]

14 Hafed Al-Ghwell: The United States Should Not Get Involved in Libya's Civil War, [online], 2018. 11. 14. Forrás: Atlanticcouncil.org [2019. 02.27.] 
alább részben - „átengedi” Oroszországnak, vagy jelentősebb szerepet felvállalva megelőzi ezt. ${ }^{15}$

A háttérbe vonulás politikája szerint a 2019. áprilisi támadás megindulása után az Egyesült Államok kivonta Líbiából a diplomáciai és terrorizmusellenes feladatokat végrehajtó, kisszámú katonai kontingensét. Az eddigi állásponttal azonban merően szembement Donald Trump reakciója - amikor a Haftar áprilisi offenzíváját elítélő saját külügyminiszterével szemben - lényegében támogatta Haftar támadását Tripoli ellen, elismerve a tábornok terrorizmusellenes erőfeszítéseit. ${ }^{16} \mathrm{Ez}$ az új megközelítés felkavarhatja az eddig is kaotikus erőviszonyokat Líbiában, azonban egyelőre inkább csak impulzív kijelentésnek tünik. A 2019 áprilisában kivont katonai erők mutatják, hogy az USA kemény eszközökkel is jelen volt Líbiában, de az országgal kapcsolatban alkalmazott politikájában inkább a puha eszközök domináltak. E tekintetben lényegi változás nem valószínüsíthető, de az Egyesült Államok szerepe kapcsán továbbra is számos kérdés nyitva áll.

\section{Kína - a gazdasági szereplő}

A kínai külpolitika pragmatikus jellegének kiváló példáját láthatjuk a líbiai válság elemzése során. Kaddáfi Líbiájában Kína az 1990-es évek közepe óta meghatározó gazdasági tényezővé akart válni, figyelme különösen a kőolaj kitermelésére irányult, ugyanakkor a líbiai kormányzat megpróbálta minél távolabb tartani a szektortól. Ellenben, számottevő volt a kínai vállalatok jelenléte az építőiparban, az infrastrukturális és távközlési beruházásokban. A 2011-es politikai fordulat megrázta és negatívan sújtotta a kínai befektetéseket. A becslések szerint a kínai gazdaságnak a 2011-es észak-afrikai események közel 20 milliárd dollárnyi veszteséget okoztak. ${ }^{17}$ A felkelés keltette kockázat miatt összeomlottak a közlekedési szektorban érdekelt China Railway, valamint az ingatlanberuházásokban érdekelt Sinohydro és China State Construction Engineering vállalatok több milliárd értékü megállapodásai. ${ }^{18} \mathrm{~A}$ líbiai felkelés során számos atrocitás érte az országban tartózkodó több tízezer kínai vendégmunkást, amely miatt és az események kiszámíthatatlansága okán a kínai kormánynak körülbelül 35 ezer állampolgárát kellett evakuálnia Líbiából. ${ }^{19}$

Politikai szempontokból vizsgálva Peking magatartását a líbiai válság eszkalációja során meglepő, hogy a korábbi kínai viselkedéstől merőben eltérő külpolitikai fordulatot tapasztalunk. Nem csupán a kínai vendégmunkások - részben társadalmi nyomására - megszervezett kimentése (számos külföldi állampolgárral együtt) vall nagyhatalmi felelősségvállalásra, hanem az ENSZ BT-ben - állandó tagként - tanúsított politikai pragmatizmus is. Kína az ENSZ BT 1970. számú, embargóról szóló határozatát megszavazta, továbbá a BT 1973. számú határozatáról szóló szavazás során tartózkodásával hozzájárult

\footnotetext{
Fishman: i. m., 94. o.

16 Samer Al-Atrush - Jennifer Jacobs - Margaret Taley: Trump Backed Libyan Strongman's Attack on Tripoli, U.S. Officials Say, [online], 2019. 04. 24. Forrás: Bloomberg.com [2019. 04. 25.]

17 Szakáli Máté: Szafarin a Sárkány: Kína befektetései Afrikában, [online], Külügyi Szemle, 14. évf., 2015/3, 75-95. o.; 85. 0 .

18 Uo. 86. o.

19 Andrew Jacobs - Jane Perlez: U.S. Wary of Its New Neighbor in Djibouti: A Chinese Naval Base, [online], 2017. 02.25. Forrás: Nytimes.com [2019. 02. 20.]
} 
a nemzetközi katonai fellépés lehetővé tételéhez. Kína ezekkel a lépésekkel megszegte saját - eddig vezérfonalként követett - belügyekbe való be nem avatkozás alapelvét. Kína az észak-afrikai térségben való mozgása során óvatos és figyelembe veszi a teljes arab világgal kialakított kapcsolatrendszerét. Líbiai szárazföldi akcióban nem szándékozott részt venni. Kína e tekintetben politikailag nem kockáztat, pragmatikusan, gazdasági érdekei mentén építi ki kapcsolatait a Kaddáfi-korszak után megjelenő líbiai vezetőkkel, frakciókkal. 2011. szeptember 12-én - hosszas óvatoskodás után - Kína is elismerte az Átmeneti Nemzeti Tanácsot. Kína támogatja továbbá az ENSZ által elismert líbiai egységkormányt és határozattan sürgeti az ENSZ rendezési tervének megvalósítását.

Az észak-afrikai ország jövőjét illetően Kína feltételezhetően nem támogatná az ország területi széttöredezését. Pekingnek az az érdeke, hogy a gazdasági befolyása kiterjesztéséhez megfelelő stabilitás, közbiztonság és kiszámíthatóság uralkodjon az országban. Kiemelkedően fontos szempont számára egy egységes felvevő piac és az energetikai szektorban nagyobb részesedés elérése. Líbia integritása Kína Tajvan-politikája és további nemzetiségi területeit érintő szeparatizmus veszélye miatt is rendkívül jelentős külpolitikai cél. Jóllehet úgy tünik, hogy Peking a líbiai felek közötti békéltető szerepet meghagyja Franciaországnak és Olaszországnak, nagyon is érdekelt Líbia újjáépítésében. Kína és az arab államok együttmüködési fórumán ${ }^{20} 2018$ júliusában Hszi Csin-ping, kínai elnök bejelentette, hogy 23 milliárd dollárt különítenek $\mathrm{el}^{21}$ az arab országok infrastruktúrájának felújítására. Ugyanakkor az is valószínüsíthető, hogy mindezen befektetésekböl Líbia csak az ENSZ által (is) szorgalmazott és felügyelt politikai választások megrendezését követően, egy teljes nemzeti felhatalmazással bíró kormány megalakulása utáni időszakban részesülhet.

Kína Líbia-politikája megértéséhez közelebbről szükséges megvizsgálni Peking Afrikában betöltött szerepét. Peking ugyanis a gazdasági kapcsolatai építése (beleértve fegyvereladásait, és az olyan illegális termékek, mint az elefántcsont kereskedelmét), illetve a humanitárius szerepvállalása révén egy új, Európához sokkal közelebbi erőteret épít ki magának. ${ }^{22} \mathrm{~A}$ világ második legnagyobb gazdasági hatalmának, Afrika első számú kereskedelmi partnerének csillapíthatatlan az energiaéhsége. Stratégiáját elösegíti, hogy a „harmadik világ” egyik vezető szereplője volt, Afrikában nincs gyarmati múltja, tehát valamelyest szívesebben engedik az afrikai vezetők nagyobb térhez országaikban. Saját belső autoriter és diktatórikus berendezkedéséből következően jellemzően nem avatkozik be a belügyekbe, gazdasági segélyeinek, kölcsöneinek feltételéül nem szabja sem a gazdasági reformokat, sem a demokrácia megerősítése érdekében szükséges jogállami és emberi jogi intézkedéseket. A kínai - főként állami - vállalatok hosszú távú szerződéseket kötnek a fejlesztési (kórház, iskolaépítés), infrastrukturális, bányászati és távközlési szektorokban, cserébe a kőolajért és az ásványkincsekért. ${ }^{23} \mathrm{~A}$ beruházásokat, támogatásokat kínai bankok hitelezik. Ez a külgazdasági stratégia nem csupán Fekete-Afrikában jellemző, hanem

\footnotetext{
20 Az együttműködés formalizálása szükséges az Egy öv, egy út kezdeményezés miatt. Highlights of Xi’s speech at ChinaArab forum, [online], 2018. 07. 10. Forrás: Chinadaily.com.cn [2019. 02. 21.]

21 Giorgio Cuscito: La Cina tornerà in Libia, [online], 2018. 07. 27. Forrás: Limesonline.com [2019. 02. 21.]

22 Engelberth István: „Chinafrica”? - Afrika a XXI. század küszöbén, [online], EU Working Papers 3/2009, 41-52. o.

23 Az úgynevezett Angola-modell szerint: „infrastruktúrát nyersanyagért”.
} 
az észak-afrikai államokban is; fóként Egyiptomban, valamint a némileg ideológiailag is közelebb álló Algériában. Kína tervei szerint Líbiában is erre a szerepre törekszik. A nagyobb befolyás elérése érdekében rendszeresek a két állam közötti bilaterális, valamint a különböző nemzetközi fórumokon zajló egyeztetések.

A 2019. februári Müncheni Biztonsági Konferencián az ENSZ rendezési tervének végrehajtását követően nagyszabású kínai-líbiai együttmüködésről beszélt Vang Ji kínai külügyminiszter Szarrádzs elnökkel. ${ }^{24}$ A beharangozott beruházások a modern selyemút - az egy öv, egy út kezdeményezés keretében fognak elkezdődni, a csatlakozásról Kína és Líbia 2018 nyarán egyetértési szándéknyilatkozatot írt alá. ${ }^{25}$ Kína részéről a líbiai kikötők elsőrendű fontosságúak lehetnek a tengeri selyemút mentén, valamint a Földközi-tenger ellenőrzése érdekében is. Számos konfliktus forrása lehet, hogy a jövőben Kína ily mértékü közelségbe kerülhet Európához.

Peking a líbiai felkelés tapasztalatait követően nagyobb körültekintéssel építi ki gazdasági erejét. Ha szükséges, létesítményeit, vendégmunkásait akár katonai erővel is meg fogja védeni. Az egy öv, egy út elképzelés mellé egy biztonsági programot is kidolgozott. Kína 2018 nyarán 49 afrikai állam és az Afrikai Unió részvételével szervezte meg az első KínaiAfrikai Védelmi és Biztonsági Fórumot. Nagy létszámmal és jelentős anyagi hozzájárulással vesz részt az ország a különböző békefenntartó missziókban, valamint a kalózkodás elleni müveletekben. Arra következtethetünk, hogy a gazdasági szerepvállalása mellett a jövőben elképzelhető a nemzetközi katonai és rendőri együttmüködésekben való részvétele, akár Líbiában is a polgárháború lezárását követő időszakban. A kínai haditengerészet gyors modernizálását, valamint a dzsibuti katonai bázis létrehozását követően felmerülhet annak az eshetősége, hogy Kína a Földközi-tengeren is hasonló jelenlétre és befolyásra törekszik majd.

2011 után az Egyesült Államok és Európa „kihátrálása” a térségből egy légüres teret hozott létre, ezt a hatalmi vákuumot Kína is egyre fokozott erőbefektetéssel próbálta betölteni. Geopolitikai érdekei megkövetelik, hogy a jövőben is föleg puha eszközökkel, de határozottan beavatkozzon a líbiai belpolitikába. ${ }^{26}$ Haftar tábornok offenzívájával kapcsolatosan Kína kivár, nem veszélyeztetheti a tervbe vett üzleti megállapodásokat. ENSZ BT-tagként ugyanakkor szavazata jelentős lehet egy várható ENSZ-határozat során. Az afrikai kontinensen és a WANA (Nyugat-Ázsia és Észak-Afrika) térségében szélesedő és mélyülő kínai szerepvállalás Európához is egyre közelebb hozza Pekinget. Ezáltal termékei könnyebben érik el az európai piacot, adott esetben az afrikai gyáraikból, továbbá - a hagyományosan az európai középhatalmak érdekszférájába tartozó térségben - az energetikai szektor, a beruházások, a kereskedelem és a piac nagyobb szeletét vághatja ki magának.

24 Lorenzo Lamperti: Cina pronta a investire in Libia. Così Pechino può salvare Africa (ed Europa), [online], 2019. 02.18. Forrás: Affaritaliani.it [2019. 02. 21.]

25 Safa Alharathly: Libya joins China’s Belt and Road Initiative, [online], 2018. 07. 13. Forrás: Libyaobserver.ly [2019. 02. 21.]. A Maghreb államok már 2013-ban aláírtak egy hasonló megállapodást.

26 Jian Junbo - Álvaro Méndez: Change and Continuity in Chinese Foreign Policy: China’s Engagement in the Libyan Civil War as a Case Study, [online], LSE Global South Unit Working Paper Series No. 5/2015. Forrás: Lse.ac.uk [2019. 02. 21.] 


\section{Oroszország - az egyre aktívabb szerepvállaló}

A 2011-es NATO-beavatkozás egyik leghangosabb kritikusa Oroszország volt, amely bár nem vétózta meg az 1973. sz. ENSZ BT-határozatot, ami a katonai intervenció jogi alapját képezte ${ }^{27}$ a beavatkozás módját nagyon élesen kritizálta. Vlagyimir Putyin akkori miniszterelnök kifejtette, hogy a „keresztes hadjáratokra” mozgósító „középkori felhívásra” emlékezteti az 1973 sz. BT-határozat, amely lehetővé teszi a beavatkozást egy állam belügyeibe. ${ }^{28}$ Líbiában a NATO-beavatkozás utáni káoszt Moszkva az USA vezette intervenciók okozta instabilitás tökéletes példájának tartva, azt a képet próbálta kialakítani magáról belföldön és külföldön egyaránt, hogy amit az Egyesült Államok „,tönkretesz”, azt Oroszország helyrehozza. $^{29}$

A líbiai felkelésre Oroszország nem reagált azonnal, a lázadókat képviselő Nemzeti Átmeneti Tanácsot (National Transitional Council - NTC) csak azután ismerte el, hogy az NTC kinyilvánította, hogy a Kaddáfi-éra összes szerződését tiszteletben fogják tartani. A forradalom után azonban, amikor úgy tünt, hogy Líbiában nyugatbarát erök kerülhetnek hatalomra, a Kreml stratégiája megváltozott.

Míg Oroszország kapcsán a nemzetközi közösség figyelme leginkább Szíriára fókuszált, Moszkva a térség többi államában is erősítette jelenlétét, a nemzetközi nagyhatalmi pozíciójának kihangsúlyozása céljával. Oroszország Líbia-politikája látszólag különbözik a szíriai szerepvállalástól, saját érdekei itt nem térnek el olyan látványosan a nemzetközi közösség többi tagjától, így külsőleg az együttmüködés dominál. Egyes líbiai kikötők és katonai bázisok megszerzésének lehetősége azonban nyugtalanságot keltett a nyugati szövetségi rendszerben.

Moszkva leglátványosabban a 2018. novemberi, palermói konferencián fejezte ki azt, hogy Líbiát saját érdekszférájának tekinti. Líbia kapcsán Oroszország kifejezte igényét a konfliktus nemzetközi közösség részvételével történő megoldására. Nyilvánvalóvá vált, hogy meghatározó szerepet kíván játszani a rendezésben, valamint hajlandó gazdaságilag és pénzügyileg is befektetni ennek érdekében. Minden valószínüség szerint diplomáciai lépései külföldi támogatókra is lelnek, hiszen az orosz Líbia-politika szinte teljesen megegyezik Egyiptoméval és az Egyesült Arab Emírségekével. Noha az Európai Unió is a békemegállapodást támogatja, az EU és tagállamainak többsége nem érdekelt Oroszország túlzott megerősödésében a térségben.

Oroszország jelenleg - Egyiptomhoz és az Egyesült Arab Emírségekhez hasonlóan - hivatalosan támogatja az ENSZ által létrehozott, tripoli székhelyü nemzeti egységkormányt (Government of National Accord - GNA), és így az egységes líbiai állam fennmaradását, emellett azonban Haftar és a tobruki hatalmi központ egyik legjelentősebb támogatójává

\footnotetext{
27 A BT-határozat elfogadása után Vitalij Csurkin orosz ENSZ-nagykövet kritizálta is a határozatot, mivel az véleménye számos fontos kérdést nyitva hagyott, és a határozat kidolgozása nem volt összhangban az ENSZ BT addig megszokott gyakorlatával. Moszkva tartózkodását egyrészt a civil lakosság megvédésének szükségességével magyarázta, másrészt azzal, hogy az Arab Liga kérte a Líbia feletti légtérzár létrehozását. Egyúttal azonban kifejtette azt a véleményét is, hogy Moszkva álláspontja szerint a 1973. számú határozat a széleskörü katonai műveletek lehetővé tétele miatt eltér az Arab Liga javaslatától.

28 TÁlAs: $i . m$.

29 Pigman, Lincoln - Orton, Kyle: Inside Putin’s Libyan Power Play, [online], 2017. 09. 14. Forrás: Foreignpolicy.com [2019. 02.10.]
} 
vált. Moszkva álláspontja szerint a tobruki jóváhagyás nélkül a nemzetközi közösség által elismert GNA nem legitim. A GNA-t az oroszok egy olyan, a Nyugat által támogatott kormánynak tekintik, amely figyelmen kívül hagyná a líbiai orosz érdekeket, és ha Moszkva nem tud befolyást gyakorolni rá és a támogatóira, úgy Oroszország számára a válság rendezésének folyamatában, valamint a háború utáni Líbia politikai és gazdasági életében való részvétel záloga a jövőben hatalomhoz jutható csoportokkal való kapcsolat ápolása.

Mindezek miatt Moszkva számára nagyon fontos Khalífa Haftar személye is, aki rendszeres vendég Oroszországban, ahol hivatalban levő vezetőként fogadják, magas rangú állami tisztviselökkel folytat hivatalos találkozókat. Haftar és Oroszország kapcsán megemlítendő, hogy Moszkva amellett, hogy a Haftart támogató, a baydai székhelyü Líbiai Központi Bank részére kb. 3 milliárd dollár értékü líbiai dínárt nyomtatott 2016-ban, ${ }^{30}$ a Haftar által vezetett, szovjet fegyvereket használó LNA (Libyan National Army) átalakításában és modernizálásában is aktívan részt vesz az orosz katonai tanácsadókon keresztül, így líbiai érdekérvényesítésében a kemény eszközök egyértelmüen megjelennek mind katonai, mind gazdasági szempontból. Amerikai és brit források szerint Oroszország Egyiptomon és az Emírségeken ${ }^{31}$ keresztül 2015 vége óta szállít fegyvereket Haftarnak, valamint orosz biztonsági magánvállalatok védenek gyárakat Bengázi környékén, és biztosítanak aknamentesítő felszerelést Haftar erőinek. Az orosz különleges erők egy nyugat-egyiptomi légi bázist (Sidi Barre) használnak a líbiai-egyiptomi határ közelében. ${ }^{32} 2018$ őszétől az is felmerült, hogy a korábban Szíriában müködő orosz Wagner-csoport zsoldosokat küldött Haftar támogatása érdekében. ${ }^{33}$

Hatftár azonban már hetvenes évei közepén jár, egészségi állapota fokozatosan romlik. Ezzel (is) hozható összefüggésbe az, hogy a lehetőségek nyitva tartása érdekében Moszkva felvette a kapcsolatot Kaddáfi leginkább reformer nézeteket valló fiával, Szajf al-Iszlám Kaddáfival is, illetve a 2019-re tervezett, még nem meghatározott rendszer szerint lebonyolított választásokon elnöki ambíciókat dédelgető, Haftarhoz közel álló Aref Ali Nayeddel. Hatalomra kerülésük esetén mindketten aktív szerepet szánnak Oroszországnak.

Haftar jelentős, de a többi líbiai hatalmi központot nem kizáró támogatása három szempontból - gazdaságilag, katonailag és nemzetközileg - fontos Oroszország számára. Egyrészt, amennyiben Haftar megragadja a politikai hatalmat, a vele kötött gazdasági szerződések pótolni tudják az arab tavasz okozta orosz gazdasági veszteségeket. ${ }^{34}$

30 Aidan Lewis: Separate banknotes symbols of Libyan disunity, financial, [online], 2016. 06. 03. Forrás: Reuters.com [2019. 02. 10.]

31 Egyiptom és az Emírségek egyértelműen Haftart támogatják, hiszen a regionális befolyásért mindketten azzal a Katarral vívnak proxyháborút, amely viszont a líbiai iszlamista frakciókat támogatja, amiket az inkább szekuláris elveket képviselő Khalífa Haftar legyőzendő ellenségnek tekint. Haftar személye kapcsán röviden meg kell említeni az egyiptomi-orosz közeledést, hiszen Oroszország számára Egyiptom egy megbízható, közeli partner, ami bázist biztosít az orosz erők esetleges műveleteihez, így Oroszország ki tudja használni Egyiptom közelségét, és a közös líbiai gazdasági, stratégiai és biztonsági érdekeiket.

32 Jo Becker - Eric Schmidt: As Trump Wavers on Libya, an ISIS Haven, Russia Presses On, [online], 2018. 02. 07. Forrás: Nytimes.com [2019. 02. 16.]

33300 Russian mercenaries fighting for warlord Khalifa Haftar in Libya, western news reports say, [online], 2019. 03.04. Forrás: Libyaobserver.ly [2019. 04. 23.]

34 Kaddáfi bukását követően Oroszország 150 millió dollár nyereségtől esett el az építési projektek, 3 milliárd dollártól az orosz vasúti szerződések, 3,5 milliárd dollártól az energetikai szerződések, és legalább 4 milliárd dollártól a Líbiával folytatott fegyverkereskedelmi szerződések miatt. L. Pigman-OrTon: i. m. 
Másrészt, Haftar támogatása lehetőséget biztosíthat a földközi-tengeri orosz katonai jelenlét megerősítésére. Így nem csupán Európa partjaihoz kerülnének közelebb az orosz erőkivetítési képességek, hanem a közel-keleti és az észak-afrikai térségek is könnyebben megközelíthetők lesznek. Már 2008-ban felmerült, hogy Bengázi közelében orosz haditengerészeti bázist létesítenek, ám ez végül nem valósult meg. ${ }^{35}$ Szíriában a tartuszi katonai kikötőt 2066-ig használhatja Oroszország, ez már megteremtette számára a tartós katonai jelenlét lehetőségét a mediterrán régióban, a tartuszi kikötő azonban túl kicsi ahhoz, hogy olyan nagyméretü hadihajókat, mint például a Kuznyecov Admirális repülőgép-hordozó, vagy egyéb kísérőhajókat befogadjon. ${ }^{36} \mathrm{Ha}$ azonban Oroszország Líbiában is haditengerészeti bázist tudna nyitni, az nem csupán a térség folyamataira való befolyását, hanem egyben az európai aggodalmakat is növelné.

Harmadrészt a regionális válságok kezeléséből kovácsolható politikai tőke hozzájárulhat Oroszország krími válság óta megtépázott megítélésének helyreállításához, hiszen Líbia az a konfliktusgóc, ahol az orosz és a nemzetközi közösség akarata látszólag leginkább konvergál.

Oroszország tehát nemcsak Haftart támogatja, hanem Tripolit is, sőt, a miszrátai milíciákkal is jó kapcsolatot tart fent, hiszen Haftar jövőbeli szerepe nem egyértelmü. Éppen ezért Moszkva nem teheti meg, hogy egyedül ezt a hatalmi központot támogassa, és a legfontosabb érintett felekkel való párhuzamos kapcsolattartás lehetővé teszi számára, hogy a felek közti közvetítő szerepében tünjön fel, ami az EU-val való tárgyalásai során is alku tárgyát képezheti. A kezdetektől támogatja tehát az ENSZ által létrehozott tripoli egységkormányt, illetve formálisan támogatja az ENSZ líbiai béketeremtő erőfeszítéseit, az ENSZ számára legfontosabb kérdésekben - mint például a Haftar által feloldani kívánt fegyverembargó kérdésében. Nyilvánvalóan a Líbiában mutatott „rugalmasságáért” cserébe Oroszországnak is lesznek elvárásai, például a szíriai háborúban játszott szerepe miatti nyugati nyomás csökkentése kapcsán. Az EU-val való kapcsolatfelvétel Líbia ügyében lehetőséget adhat az oroszok számára a tagállamok migrációval kapcsolatos ellentéteinek kihasználására, a tagállamok közti aktuális erőviszonyok feltérképezésére külpolitikai ügyekben, így a gyengébb tagállamok kiválasztásával tesztelheti, hogy az uniós tagállamok mennyire hajlandók nyomást gyakorolni rá - például Ukrajna vonatkozásában. ${ }^{37}$ Összességében Oroszország líbiai mozgástere szélesnek tekinthető: lehetőségei a frakciók közti közvetítő szereptől a katonai konfliktusok mélyítéséig és elhúzódásáig terjednek. Arra azonban fel kell készülnie a nemzetközi közösségnek, hogy a nemzetközi közösséggel való együttmüködésnek Oroszország előbb vagy utóbb meg fogja kérni az árát.

Moszkva számára kedvezőbb lenne egy müködőképes koalíciós kormány létrejötte, amiben Haftar felel a hadseregért, mint egy teljesen Haftar irányítása alatti kormány. A koalíciós megoldás ugyanis a jelenleg rivalizáló hatalmi központok közti békéltető folyamatok beindulásával a hosszú távú gazdasági befektetések, és katonai objektumok

\footnotetext{
5 Tom PARfitt: Gadafy offers Russia a naval base in Libya, [online], 2008. 11. 01. Forrás: The Guardian [2019. 02. 10.]

36 Wolfgang Pusztar: The Haftar-Russia Link and the Military Plan of the LNA, [online], 2017. 02. 02. Forrás: Ispionline. it [2019. 02. 10.]

37 Nikolay Kozhanov: Moscow's Presence in Libya Is a New Challenge for the West, [online], 2017. 05. 30. Forrás: Chathamhouse.org [2019. 02. 12.]
} 
miatt fontos stabilizáció lehetőségét teremtené meg. Az azonban, hogy Oroszország nyitott a kapcsolatfelvételre minden érintett líbiai féllel, garantálja számára az előnyös pozíciókat, a rendezési folyamatok és a 2019-es választások eredményétől függetlenül. A 2019 áprilisában indított Haftar-offenzíva kapcsán megjegyzendő, hogy egyes diplomáciai források szerint orosz felségjelzésủ repülögépek tartózkodnak Bengáziban. Oroszország nem fogadta el a britek által beterjesztett BT-határozattervezetet, amely Haftart tette volna felelössé a felerősödő összecsapásokért, ${ }^{38}$ ugyanakkor hivatalosan cáfolta, hogy támogatná a Tripoli elleni Haftar-offenzívát. ${ }^{39}$

\section{Európai államok}

\section{Franciaország - a leggyorsabban reagáló}

A 2011-es líbiai eseményeket, valamint az arra adott nemzetközi válaszokat Franciaország több szempontból is érdeklödve figyelte. Elöször is, a regnáló elnök, Nicolas Sarkozy, a közelgő francia elnökválasztás előtt lehetőségként látta a líbiai beavatkozást a korábbi, kétes sikerü külpolitikai lépések mérlegének javítására. Egy sikeres katonai beavatkozással politikai népszerüségét kívánta növelni. Az unió a Mediterráneumért kezdeményezés lényegében megbukott, az afganisztáni szerepvállalás aktivizálása, valamint a NATO katonai szervezetébe való reintegráció sem váltotta be a hozzá füzött politikai reményeket. Másodszor az ország érdekeit is szem előtt tartva, Sarkozy fontosnak találta az észak-afrikai térségre irányuló francia befolyás növelését. ${ }^{40}$ Harmadszor, a 2010-ben kőolajimportjának $18 \%$-át Líbiából fedező ország ${ }^{41}$ még nagyobb részesedést igényelt az észak-afrikai állam olajexportjából. ${ }^{42}$ Negyedszer, Franciaország megfelelő lehetőségnek találta ezt az időszakot a katonai erejének újraértékelésére a világban. Mindezt a NATO-ba való visszatagozódás és a szövetségi rendszer gyakorlati működésének aktív tesztelésével, valamint a 2010 novemberében az Egyesült Királysággal frissen megkötött Lancaster House megállapodás gyakorlatban való próbájával kívánta elősegíteni. ${ }^{43}$

A helyzetben rejlő lehetőséget látva, Franciaország és az Egyesült Királyság együtt nyújtotta be az ENSZ BT 1973 sz. határozatának alapjául szolgáló javaslattervezetet, amelyet 2011. március 17-én fogadtak el. ${ }^{44} \mathrm{~A}$ dátumnak azért is van jelentősége, hiszen a határozat elfogadását követően, a még folyamatban lévő tárgyalásokkal párhuzamosan, Franciaország március 19-én már meg is kezdte a líbiai célpontok bombázását. A lépés elhamarkodottnak bizonyult és a nemzetközi közösség bírálatát vonta maga után, hiszen a francia beavatkozás előzetes egyeztetések nélkül indult meg. Franciaország azonban nem csak a katonai

38 Michelle Nichols: U.S., Russia say cannot support a U.N. call for Libya truce: diplomats, [online], 2019. 05. 19. Forrás: Reuters.com [2019. 05. 23.]

39 Russia disowns Libya's General Haftar, [online], 2019. 04. 06. Forrás: Middleeastmonitor.com [2019. 04. 23.]

40 Libya: Examination of intervention and collapse and the UK's future policy options, [online], 2016. 09. 14., 10-11. o. House of Commons Foreign Affairs Committee. Forrás: Parliament.uk [2019. 04. 22.]

${ }_{41}$ Where does France import Crude Petroleum from?, [online], 2010. Forrás: Mit.edu [2019. 04. 22.]

42 Libya: Examination of intervention and collapse and the UK's future policy options: $i . m$.

43 TÁLAs: $i$. m., 68. o.

44 A Biztonsági Tanács 1973 (2011) számú határozata a Líbia fölötti repüléstilalmi övezet létesítéséről és a civil lakosság védelmére minden szükséges intézkedés megtételéröl, [online], 2011. 03. 18. Forrás: Grotius.hu [2019. 04. 22.] 
beavatkozást illetően volt első a líbiai események kapcsán. 2011. március 10-én elsőként fogadták el az újonnan létrehozott Nemzeti Átmeneti Tanácsot (NTC). Minthogy ezt is az Európai Tanács líbiai helyzetről tervezett egyeztetése elött tette meg a francia kormány, ez a lépés sem bizonyult maradéktalanul sikeresnek. ${ }^{45}$

A brit-francia megállapodás első közös gyakorlatát, a Southern Mistralt 2011. március 21-25-re tervezték. A Líbiában kialakult helyzet kísérteties másaként ható szcenáriót végül nem a gyakorlat keretén belül, hanem élesben hajtották végre a kijelölt erők, már a NATO égisze alatt létrejött műveletben. ${ }^{46} \mathrm{~A}$ kezdetben francia vezetésű koalíciós műveletet követően március végén az Operation Unified Protector követte, amelyben a francia erők jelentös hozzájárulással vettek részt. ${ }^{47} \mathrm{~A}$ francia köztudatba a beavatkozás Opération Harmattan néven vonult be, amely jelentős légi és haditengerészeti komponenst sorakoztatott fel. Ez 16 Mirage 2000 vadászbombázó, 5 Rafale vadászbombázó, egy Atlantique-2 tengeri járőrrepülögép, valamint a haditengerészeti részről két fregatt, egy tengeralattjáró, valamint egy repülőgép-hordozó bevonását jelentette a műveletekbe, amely a még Franciaország területén állomásozó, teherszállító gépekkel és $A W A C{ }^{48}$-szel kiegészíthető volt. ${ }^{49} \mathrm{~A}$ művelet 2011 októberében ért véget, és gyakorlatilag Kaddáfi október 20-i halálával a NATO befejezettnek nyilvánította a műveletet. ${ }^{50} \mathrm{~A}$ hirtelen kivonulás az egyik részről diadalittas cikkeket szült a sikeres NATO-beavatkozásról, ${ }^{51}$ a másik oldalon pedig a felelötlen beavatkozást, és a még felelötlenebb kivonulást ostorozza. ${ }^{52}$ Tény, hogy a műveletek vélt céljának elérése (Kaddáfi halála) után nagyon gyorsan kivonult a nemzetközi közösség, így Franciaország is Líbiából, mint később kiderült, a rendkívül fragmentált helyi csoportokra hagyva a rendezést.

A francia beavatkozás mérlege felemás eredményeket hozott. Politikailag Párizs mindent megtett annak érdekében, hogy Líbia ne csússzon ki a markából. A diplomáciai kapcsolatok még a legválságosabb időszakban sem szakadtak meg a két ország között..$^{53}$ Ez a zavartalanság most megszűnni látszik. A GNA 2019 áprilisában a diplomáciai kapcsolatok teljes körü felfüggesztése mellett döntött Franciaország Haftarral folytatott kétes ügyletei miatt. ${ }^{54} \mathrm{~A}$ kitüzött gazdasági cél, a kőolajpiac francia dominanciája nem teljesült. A kőolajimport ugyanis ahelyett, hogy növekedett volna, 2017-re nagyjából a harmadára csökkent, és nem is érte el a válság előtti szintet. ${ }^{55}$

\footnotetext{
45 Madelene Lindström - Kristina Zetterlund: Setting the Stage for the Military Intervention in Libya, [online], 2012. 10., 17. o. Forrás: Foi.se [2019. 04. 22.]

46 Michel Chossudovsky: When War Games Go Live: "Staging” a "Humanitarian War" against "SOUTHLAND”, [online], 2011. 04. 16. Forrás: Globalresearch.ca [2019. 04. 22.]

47 NATO and Libya (Archived), [online], 2015. 11. 09. Forrás: Nato.int [2019. 04. 22.]

48 Repülőgép-fedélzeti Korai Előrejelző és Irányító Rendszer.

49 Lopération Harmattan, [online], 2011. 09. 27. Forrás: Defense.gouv.fr [2019. 04. 22.]

50 NATO and Libya (Archived), [online], 2015. 11. 09. Forrás: Nato.int [2019. 04. 22.]

51 Ivo H. DAAlder - James G. STAVridis: NATO’s Victory in Libya, [online], 2012. 02. 02. Forrás: Foreignaffairs.com [2019. 04. 22.]

52 Dominique DAvid: Libye: intervenir, encore?, [online], 2016. 04. 12. Forrás: Ifri.org [2019. 04. 22.]

53 Libey - Relations bilatérales, [online]. Forrás: Diplomatie.gouv.fr [2019. 04. 22.]

54 Alice TideY: Libya's UN-backed government suspends cooperation with France, accuses it of backing rebel forces, [online], 2019. 04. 19. Forrás: Euronews.com [2019. 04. 30.]

55 Where does France import Crude Petroleum from?, [online], 2017. Forrás: Mit.edu [2019. 04. 30.]
} 
A 2011 óta eltelt időszakban a francia stratégia szinte semmit sem változott Líbia tekintetében. Három irányvonalat azonban el lehet különíteni. Az első az ENSZ döntéseit tiszteletben tartó, azokkal koherens stratégia. A második irányvonal erősen a kemény eszközöket részesíti elönyben, és a francia Száhel-szaharai stratégiát követi Líbiával szemben is. ${ }^{56}$ Ennek célja többek között a terrorizmus elleni küzdelem, valamint a radikalizáció terjedésének megelőzése, valamint Franciaország primátusának megörzése/megszerzése a régióban. ${ }^{57} \mathrm{~A}$ harmadik irányvonal nem meglepő módon a gazdasági érdekeket helyezi elötérbe. ${ }^{58}$

Franciaország hivatalosan jelenleg is az ENSZ által létrehozott GNA-t támogatja, és részt vesz a szervezet líbiai helyzet rendezését célzó közvetítő tevékenységében. Ezt alátámasztandó, 2017-ben Párizs még egy konferenciát is szervezett a szemben álló felekkel a kialakult helyzet békés rendezésére. Ez, mint több más korábbi francia lépés Líbiát illetően, szintén felemásra sikerült, hiszen Olaszország kimaradt a meghívottak listájáról. ${ }^{59}$ Ekkor már egyre világosabbá vált a két európai hatalom közötti nyílt rivalizálás Líbia további sorsával kapcsolatban. A GNA támogatása kapcsán ugyanakkor Párizs egyre kevésbé hiteles szereplö, hiszen vélhetően 2015 óta Khalífa Haftart támogatja a háttérben. Ez akkor vált különösen szembetűnővé, amikor egy helikopter-baleset kapcsán kiderült, hogy Haftar a francia különleges erők támogatását élvezhette az Iszlám Állam ellen folytatott harcokban. ${ }^{60}$

Nem ez volt az egyetlen esemény, amely francia katonai jelenlétre utal. 2019 februárjában egy vitatható célú légi müvelet indult meg Csád északi régióiban. ${ }^{61} \mathrm{Az}$ időpont egybeesett Haftar délnyugat líbiai hadjáratával, amely során a jelentősebb olajkutakat el is foglalta. ${ }^{62}$ Ez a terület közel esik Csád és Niger északi határaihoz, ami azért is érdekes, mert a francia Barkán müvelet ezekben a régiókban tevékenykedik, így jelentős katonai eró állomásozik Líbia közvetlen szomszédságában. Hivatalosan nincsenek francia katonák tehát Líbiában. A Tripoli ellen, április 4-én megindított offenzíva is számot tarthatott a francia érdeklődésre, hiszen áprilisban több francia állampolgárságú, felfegyverzett személy ellen intézkedtek a tunéziai hatóságok a tunéziai-líbiai határon. ${ }^{63}$

A francia politika mindenféleképpen békepárti, de az elképzelés nem feltétlenül egy demokratikus megoldás, hanem egy stabil, Franciaországgal jó kapcsolatot ápoló Líbia víziója. Ezt jelen pillanatban leginkább a kőolajkutakat is birtokló, a francia segítséget elfogadó Haftar tábornok testesíti meg. Amennyiben Haftar barátsága kitart, és a Tripoli elleni offenzíva is sikeres lesz - amelyre ugyanakkor egyre kevesebb az esély -, az a francia gazdasági kapcsolatok további fejlesztésével is járna. Ezzel Franciaország végre elérhetné a kitüzött célt, miszerint befolyásosabb szövetségese lesz Líbiának, mint Olaszország, vagy bármelyik másik nemzetközi szereplő. A Haftarral való együttmüködés azonban jelentősen erodálta

\footnotetext{
56 BACHIR, Malek: Les «trois politiques» de la France en Libye, [online], 2017. 07. 25. Forrás: Middleeasteye.net [2019. 04. 22.] France, committed to assisting the countries of the Sahel, [online], 2015. 11. 25. Forrás: Delegfrance.org [2019. 04. 30.]

58 Malek BACHIR: Les «trois politiques» de la France en Libye, [online], 2017. 07. 25. Forrás: Middleeasteye.net [2019. 04. 22.]

59 Paul TAYloR: France's double game in Libya, [online], 2019. 04. 17. Forrás: Politico.eu [2019. 04. 30.]

60 French special forces withdraw from Libya's Benghazi, [online], 2016. 08. 11. Forrás: Worldbulletin.net [2019. 04. 22.]

${ }_{61}$ Alcyone Wemä̈re: L’intervention militaire française au nord du Tchad pose question, [online], 2019. 02. 07. Forrás: France24.com [2019. 04. 22.]

62 Jeremy BinniE: LNA advances across southwest Libya. Jane’s Defence Weekly, 56. évf., 2019/11, 16. o.

63 Armed men crossing from Libya alleged to be French spies, [online], 2019. 04. 23. Forrás: Aljazeera.com [2019. 04. 30.]
} 
Franciaország pozitív megítélését a GNA köreiben, így Párizsnak a jelenlegi felállás tartós fennmaradása már nem érdeke. Az is látható, hogy amennyiben a Szarrádzs-kormányzat túléli az offenzívát, Franciaország kezéből lassan kicsúszik a kívánt politikai, gazdasági célok beteljesítésének lehetősége. ${ }^{64}$

\section{Olaszország - a legrégebbi szereplö}

Líbia területén a gyarmati korszak óta megfigyelhető a brit-francia-olasz rivalizálás, amely szinte teljesen megszünt Kaddáfi hatalomra lépését és nemzetközi elszigeteltségét követöen. Olaszország a kilencvenes évek végétől jelentős előnyre tett szert a Líbiával való diplomáciai és gazdasági kapcsolatok felvétele terén. A kétoldalú kapcsolatok tovább erősödtek, amikor a nemzetközi közösség 2003-ban felfüggesztette a Líbiával szemben alkalmazott szankciókat. A kapcsolatok csúcsát a 2008-as barátsági, partnerségi és együttmüködési szerződés (bengázi szerződés) jelentette. A „privilegizált kapcsolatot” létrehozó szerződés többek között az illegális migráció megállítását is célul tűzte ki. ${ }^{65} \mathrm{~A}$ szerződés mind a mai napig a két ország közötti kapcsolatok alapját képezi.

A 2011 márciusától induló légitámadásokban Olaszország, bár politikai szinten hezitált, kezdetektől részt vett. Kezdetben elsősorban logisztikai infrastruktúrát és katonai bázisait bocsátotta a koalíciós erők rendelkezésére. A líbiai konfliktus kitörésekor a határozatlan olasz reakció hátterében nem csupán a gazdasági okok, hanem a két állam közötti barátsági szerződés és a Berlusconi és Kaddáfi közötti személyes barátság is állt. Április végén, a belpolitikai vitákat követően az olasz kormány végül úgy döntött, hogy közvetlenül is részt vesz a bombázásokban. ${ }^{66} \mathrm{~A}$ válságot követően az Egyesült Királyság és Franciaország líbiai befolyásának növekedésével egyidejüleg Olaszország gazdasági érdekei csorbultak elsősorban, így mind puha, mind pedig kemény hatalmi eszközökkel vezető szerepének visszaállítására törekedett.

A Kaddáfi-rendszer bukását követően Olaszország elsősorban a Líbia felől érkező menekült- és irreguláris migrációs hullám megállításával volt elfoglalva. A Berlusconi bukását követően hatalomra kerülő Monti-kormány idején már megállapodást kötöttek a nemzetközi erők, a Róma által is támogatott líbiai kormánnyal az irreguláris migráció megállítása érdekében. 2013-ban a Lampedusa partjainál bekövetkezett hajószerencsétlenséget követően az olasz kormány egy humanitárius-katonai misszió, a Mare Nostrum indításáról döntött. ${ }^{67}$ Mivel Olaszország önmagában nem volt képes fellépni az egyre szélesedő válsággal szemben, így az európai uniós eszközök megerősítésében vált érdekeltté. Kezdetektől támogatta, sőt kérte a Frontex Triton müveletének, majd 2015-től az EU közös biztonság és védelempolitika EUNAVFORMED Sophia müveletének elindítását, amelynek mandátu-

64 TAYLOR: $i$. $m$.

65 Legge 6 febbraio 2009, n. 7. Ratifica ed esecuzione del Trattato di amicizia, partenariato e cooperazione tra la Repubblica italiana e la Grande Giamahiria araba libica popolare socialista, fatto a Bengasi il 30 agosto 2008. Gazzetta Ufficiale, No. 40., [online], 2009. 02. 18. Forrás: Parlamento.it [2019. 04. 23.]

${ }^{66}$ Molnár Anna: Olaszország és Líbia kapcsolata a 2011-es polgárháború tükrében, [online], Kül-Világ, 8. évf. 2011/4, 1-26. o. [2019. 05. 24.]

67 Mare Nostrum, [online]. Forrás: Difesa.it [2019. 04. 23.] 
ma 2016-tól a líbiai parti őrség kiképzésére is kiterjedt. Az olasz kormány emellett jelentős szerepet vállalt a parti örség felszerelésében is. ${ }^{68}$

Olaszország az utóbbi években lehetőségeihez képest minden rendelkezésére álló puha és kemény külpolitikai eszközzel támogatta a nemzetközileg elismert líbiai egységkormány megerősítését, amelynek kérésére Róma 2016 szeptemberében 300 fös katonai kórházat létesített (Hippokratész misszió) Miszratában az ISIS ellen harcolók támogatása érdekében. ${ }^{69}$ Emellett 2016-tól Olaszország különleges müveleti erőkkel is támogatta az egységkormány megerősítését. ${ }^{70}$ Mindemellett az olasz kormányzat számára is jelentős kihívást jelentett, hogy az országba áramló irreguláris migrációs hullám számos területen összefonódott a hagyományos és az országban újonnan megtelepedő szervezett bünözői csoportok tevékenységével. Nem véletlen, hogy Olaszország 2017 augusztusában a haditengerészet két hajójának a líbiai parti örségnek nyújtott közvetlen támogatásról, majd szeptemberben egy körülbelül 100 csendőrből álló katonai misszió Líbia déli határára történő telepítéséről döntött.

Róma azonban nem csupán az uniós, hanem a bilaterális és a nemzetközi szintü eszközök alkalmazásában is erősen érdekelt. 2017-ben, amikor az Egyesült Nemzetek Menekültügyi Főbiztossága (UNHCR) bejelentette, hogy 2010 után ismét visszatér Líbiába, és ott táborokat hoz létre, az olasz kormány támogatásáról biztosította a szervezetet. ${ }^{71}$ Fontos megjegyezni azt is, hogy a kormány 2017 februárjában migrációs megállapodást (Memorandum of Understanding - MoU) kötött a líbiai nemzeti egységkormány miniszterelnökével, Fájez esz-Szarráddzsal. ${ }^{72}$ Ezek az erőfeszítések hosszú távon csak akkor járhatnak sikerrel, ha egy valódi központi kormányzat vezetésével és a nemzetközi szereplők segítségével Líbia egysége ismét megvalósul, rendeződik a jelenleg rendkívül bonyolult hatalmi helyzet, és stabilizálódik a biztonsági környezet. Közös európai megoldások hiányában azonban Olaszországban tovább erősödött az a nézet, hogy az ország valójában szinte egyedül maradt az egységes Líbiát támogatók körében, és ezzel együtt a rendkívül bonyolult migrációs válság kezelésében.

Olaszország számára a Líbiával folytatott gazdasági kapcsolatok a romló biztonsági helyzet ellenére továbbra is meghatározóak maradtak. 2017-ben az afrikai államok közül Líbia volt Olaszország ötödik legfontosabb kereskedelmi partnere. A térségből érkező földgáz- és olajszállítmányok tekintetében csupán Algéria előzte meg. Az országban 1959 óta működő ENI mind a mai napig meghatározó szereplője a líbiai energiaiparnak. A gazdasági és politikai kapcsolatok fontosságát mutatja, hogy 2018-ban is több miniszteri szintü találkozó volt Líbiában. 2018 júniusában Moavero Milanese külügyminiszter, augusztusban pedig Elisabetta Trenta védelmi miniszter látogatott az országba. ${ }^{73}$

68 Molnár Anna: Az EUNAVFOR MED Sophia művelet. In: MolnáR Anna - KomLósı, Orsolya (szerk.): Az Európai Unió mediterrán térséggel összefüggő kapcsolata. Párbeszéd és konfliktusok, [online], Dialóg Campus Kiadó, Budapest, 2019, 95-123. o.

69 Operazione Ippocrate, Schieramento di un ospedale da campo in Libia, [online]. Forrás: Difesa.it [2019. 04. 23.]

70 Sergio RAmE: Forze speciali italiane in Libia: ecco il documento top secret, [online], 2016. 08. 10. Forrás: Ilgiornale.it [2017. 09. 22.]

71 Pinotti: «L'Onu ritorna in Libia, più controlli su chi parte», [online], 2017. 04. 29. Forrás: Partitodemocratico.it [2019. 04. 22.]

72 Migranti: accordo Italia-Libia, il testo del memorandum, [online], 2017. 02. 02. Forrás: Repubblica.it [2019. 04. 22.]

73 Relazioni economiche Italia-Libia, [online]. Forrás: Esteri.it [2019. 04. 22.] 
Olaszország számára rendkívül fontos a líbiai helyzet rendezése és a stabilizációs folyamat előmozdítása. A 2018-tól hatalmon lévő Conte-kormány az európai uniós megoldások helyett elsősorban a bilaterális kapcsolatokra igyekezett nagyobb hangsúlyt helyezni. 2018 őszén az olasz kormány kezdeményezte egy nemzetközi konferencia megrendezését. 2018. november 12-13-án Palermóban szervezték a „Líbiáért Líbiával” (For Libya With Libya) elnevezésü konferenciát, amelynek célja az ország újraegyesítésének elősegítése volt. Annak ellenére, hogy az olasz kormány nagy hangsúlyt fektetett a konferencia megszervezésére, azon a nagyhatalmak nem legfelsőbb, hanem csak miniszteri szintű delegációkkal képviseltették magukat. A találkozón azonban a legfontosabb líbiai vezetők (Fájez esz-Szarrádzs miniszterelnök, Agíla Száleh a Képviselőház elnöke, Khaled al-Misrí az Államtanács elnöke és Khalífa Haftar, a Líbiai Nemzeti Hadsereg parancsnoka) részt vettek, illetve velük két- és többoldalú egyeztetéseket folytattak. Bár nem minden résztvevő volt elégedett a tárgyalások eredményeivel, a konferencián megegyeztek a következő évi nemzeti választásokat előkészítő újabb nemzeti szintű konferencia összehívásáról. Annak ellenére, hogy a konferencia diplomáciai jelentőségét az elemzők többsége nem vitatta, valójában nem váltotta be a hozzáfütött reményeket - 2019 áprilisában ismét polgárháborús helyzet alakult ki Líbiában. ${ }^{74}$

Olaszország a válság rendezése érdekében kezdetektől mind puha (például diplomáciai), mind kemény, katonai eszközöket is alkalmazott. Az ország elsődleges külpolitikai érdeke, hogy Líbia bel- és biztonságpolitikai helyzete rendeződjön. Ehhez az európai és a transzatlanti partnerek is szükségesek lennének, Róma ugyanis egyedül nem képes a líbiai helyzetet megoldani. Jelenleg azonban az amerikai partner nem kíván katonai erőkkel részt venni a rendezésben, a legfőbb európai partner, Franciaország pedig az olasz külpolitikai törekvésekkel éppen ellentétes lépéseket tett. Az amúgy is elmérgesedett olasz-francia kapcsolatokra további árnyékot vetett, hogy az olasz kormány már 2018 szeptemberében is nyíltan Macront okolta a helyzet romlásával. Véleményük szerint Franciaország jelentős támogatásával tudott csak Haftar tábornok megerősödni. ${ }^{75}$

A 2019. áprilisi harcokat követően Olaszország a katonai helyett egyértelműen a diplomáciai megoldást támogatta. Ennek érdekében az olasz miniszterelnök 2019 májusában mind az orosz, mind pedig a tunéziai elnökkel tárgyalt telefonon. Elemzők azonban továbbra is aggodalommal figyelték, hogy a javuló olasz-orosz kapcsolatok is hozzájárulhatnak Oroszország további erősödéséhez a térségben. ${ }^{76}$ Noha Róma vezető szerepet kíván játszani a konfliktus rendezésében, Párizs nélkül ez aligha lehetséges. Fontos előrelépésnek tekinthető, hogy a május 14-ei uniós külügyi tanácsi ülés után az olasz és francia külügyminiszterek közös nyilatkozatot adtak ki az azonnali tüzszünet és az ENSZ égisze alatt folytatott tárgyalások szükségességéről. ${ }^{77}$

\footnotetext{
7 VArvelli, Arturo: Libia: conferenza di Palermo, il bilancio dell'Italia, [online], 2018. 12. 12. Forrás: Affarinternazionali. it [2019. 04. 23.]

75 Libia, Conte e Salvini: „No a interventi militari”. Il ministro dell'Interno: „Cè dietro qualcuno”. E attacca la Francia, [online], 2018. 09. 03. Forrás: Repubblica.it [2019. 04. 23.]

76 Conte: Italia, Russia e Tunisia respingono una soluzione militare in Libia, [online], 2019. 05. 02. Forrás: Luiss.it [2019. 05. 12.]

77 Dichiarazione congiunta del Ministro dell'Europa e degli affari esteri, Jean-Yves Le Drian, e del Ministro degli affari esteri e della cooperazione internazionale, Enzo Moavero Milanesi (13 maggio 2019), [online], 2019. 05. 13. Forrás: Esteri. it [2019. 05. 15.]
} 


\section{Németország - a donorország}

Németország hagyományos szövetségeseivel ellentétben nem szavazta meg a repüléstilalmi zónáról döntő 1970. sz. BT-határozatot, így tartózkodásával Kína és Oroszország társaságában találta magát. ${ }^{78}$ A felkelésekről érkező első hírek után Angela Merkel kancellár és Guido Westerwelle külügyminiszter Kaddáfit lemondásra szólította fel, és befagyasztotta a líbiai vezetők németországi számláit, a repüléstilalmi zóna kikényszerítése kapcsán azonban kétségüket fejezték ki. ${ }^{79}$ A tartózkodás egyben azt is jelentette, hogy Németország relatív fontossága csökkent. Mivel a döntéshozatal az Európai Tanácstól gyorsan a NATOhoz került, így Berlin nem tudott az egyesülés óta külpolitikájának preferált eszközeként használt tárgyalásokkal, és nem katonai jellegü kényszerítő intézkedésekkel részt venni a válság rendezésében. ${ }^{80}$

A BT-határozattól való tartózkodás azért jelentős, mert így a beavatkozásban részt vevő országokkal ellentétben Németország hitele nem sérült a líbiaiak szemében, és mivel nincsenek jelentős gazdasági érdekei a líbiai olajiparban, így hitelesebben tudná felvállalni a pártatlan közvetítő szerepet a felek között. ${ }^{81} 2019$ áprilisában Németország vezette az ENSZ Biztonsági Tanácsának elnökségét, az áprilisi offenzívára a BT sürgősségi összehívását kérte, de a többi vizsgált országhoz képest a fejleményekre adott reakciója lényegében súlytalan volt, ami a Líbiában alkalmazott puha eszközei alapján nem meglepö.

Németország a kezdetektől fogva egyértelmüen támogatta a nemzetközileg elismert egységkormányt, a líbiai erőviszonyok változását politikai kapcsolatépítő törekvései nem követik, s ellentétben az uniós tagállamokkal, elsősorban Franciaországgal és Olaszországgal, Berlin sem Haftarral, sem a milíciákkal nem keresi a politikai dialógus lehetőségét. A nemzeti egységkormány kapcsán ki kell emelni, hogy az ENSZ-fötitkár líbiai különleges megbízotti pozícióját 2015 novemberétől 2017 júniusáig a német karrierdiplomata, Martin Kobler töltötte be, és az ő irányításával írták alá ${ }^{82}$ a Líbia jövőjét rendezni hivatott szkhíráti megállapodást.

Bár politikailag nem, gazdaságilag - legnagyobb donorországként - fontos szerepet játszik a líbiai rendezésében. 2017-ben Németország körülbelül 233 millió eurót adományozott Líbiának, amelynek nagy részét - mintegy 200 millió eurót - a migrációhoz köthető területek kezelésére fordították (beleértve a líbiai belső menekültek helyzetének rendezését

78 Jelen tanulmánynak nem célja a német tartózkodás hátterében levő okok elemzése, azonban ki kell emelni, hogy a külpolitikai identitásával az egyesülés óta küzdő Németországban az afganisztáni részvétel jelentősen befolyásolta a közbeszédet: a német lakosság nem támogatta a katonai részvételt. A BT-szavazás kb. 2 héttel a németországi regionális választások előtt volt, így a pártok számára nem volt felvállalható opció a lakosság akaratával való szembemenetel.

79 Fabian Neuen: Germany's nightmare: Responding to the Libyan Crisis, [online], 2011. 09. 28. Forrás: Fairobserver.com [2019. 03. 12.]

80 Inez von Weitershausen - David Schäfer - Wolfgang Wessels: A 'Primus Inter Pares' in EU Foreign Policy? German Leadership in the European Council during the Libyan and Ukrainian Crises. German Politics, DOI: 10.1080/09644008.2019.1583328

81 The Berlin Pulse 2017 - German Foreign Policy in Perspective, [online], 2017/11, 27. o. Forrás: Koerber-stiftung.de [2019. 03. 23.]

82 Szkhírát kapcsán meg kell jegyezni, hogy bár azt Kobler vezetésével írták alá, az előkészítő folyamatok nagy része elődje, Bernardino Leon érdeme. 
is). ${ }^{83} \mathrm{~A}$ támogatás a teljes ország területére kiterjed, a semlegesség fenntartása miatt a német adományok nem a központi kormányhoz, hanem a helyi közösségekhez érkeznek a teljes ország területén, a három nagy tartomány között nagyjából egyenlően elosztva.

Összességében Németország a Líbia helyzetéről folyó politikai vitákban nem vesz részt, álláspontja szerint a jövő Líbiájáról a líbiaiaknak kell dönteni, az ország stabilizálását puha, gazdasági eszközökkel támogatja. A helyzet rendezésében Berlin kiemelten érdekelt, hiszen egyes statisztikák szerint a Líbián keresztül Európába érkezett irreguláris migránsok 80-90\%-ának Németország elérése a célja. ${ }^{84}$

\section{Regionális hatalmak}

\section{Egyiptom - a keleti rész örök támogatója}

E tanulmányban vizsgált országok közül egyedül Egyiptomnak van szárazföldi határa Líbiával, ebből kifolyólag a Nílus menti állam külpolitikájában kiemelkedő helyet foglal el a líbiai helyzet rendezési folyamata. Abdel-Fattáh al-Szíszi geopolitikai elképzelései azonban messze túlmutatnak a határ menti biztonság megteremtésén. Egyiptom regionális hatalmi szerepet kíván elérni a térségben, amelynek érdekében Kairó megpróbál egyensúlyozni az Egyesült Államok, Oroszország és Kína befolyása között. Al-Szíszi Nasszerre emlékeztető politikai fellépése ${ }^{85}$ - a nagyhatalmakkal fenntartott kapcsolatok egyiptomi érdekek szerint történő alakítása - egy hosszú távra tervezett, önálló egyiptomi geopolitikát feltételez. A kairói stabilitás - még ha autoriter is - jelenleg megfelel a nagyhatalmaknak és az Európai Uniónak is. Az idén februárban első alkalommal megrendezett, az Európai Unió és az Arab Liga csúcstalálkozó helyszínválasztását, Sarm es-Sejket szimbolikus jelentőségünek is vélhetjük.

Egyiptom éppúgy megélte az „arab tavaszt”, mint Líbia, ugyanakkor a felkelést követő események más irányba sodorták a két országot. Egyiptomban Mubárakot követően Morszi, majd a puccs után al-Szíszi került hatalomra, aki a katonai diktatúra kiépítésének Kaddáfi-féle mintáját követi. ${ }^{86} \mathrm{Az}$ egyiptomi vezetés részéről napjaink líbiai belpolitikai palettáján Haftar tábornok élvezi a legnagyobb támogatottságot. A következő választásokon várhatóan elindul a néhai Kaddáfi elnök fia, Szajf al-Iszlám Kaddáfi is, akit egyes források szerint Kairó titkos támogatásban részesít. ${ }^{87}$ Egyiptom Líbia-politikáját al-Szíszi belpolitikai céljai éppúgy meghatározzák, mint a külpolitikai mozgástere. Az Egyesült Arab Emírségek és Szaúd-Arábia támogatásával Egyiptom célja a Muszlim Testvériség teljes kizárása a hatalomból, nem csupán az országban, hanem a szomszédos Líbiában is. Haftar tábornok a politikai iszlám és az iszlamista harcosok elleni fellépésével határozott egyiptomi támogatást vívott ki magának. Khalífa Haftar régóta jó kapcsolatokat ápol Egyiptommal. Az 1973-as

\footnotetext{
83 Michael Cousins: Germany continues to lead foreign financial support for Libya, [online], 2018. 01. 03. Forrás: Libyaherald.com [2019. 04. 01.]

84 Cousins: $i . m$.

85 Amy Hawthorne - Andrew Miller: Worse Than Mubarak, [online], 2019. 02. 27. Forrás: Foreignpolicy.com [2019. 02. 28.]

86 Uo.

87 Video shows Egypt soldiers fighting in Libya’s Derna, [online], 2019. 02. 19. Forrás: Middleeastmonitor.com [2019. 02. 27.]
} 
jom kippuri háborúban ő vezette a líbiai tüzérségi osztagot, és a háborús szerepvállalásáért egyiptomi becsületrendet kapott. Az idősödő tábornok akár al-Szíszi hatalomra lépésének példáját is követheti a 2019-re csúszott választásokat követően.

A nemzetközi fegyverembargó ellenére, illetve annak feloldását sürgetve, Egyiptom és Oroszország fegyverekkel, hírszerzési információkkal, logisztikai segítséggel és katonákkal is támogatja Haftar erőit. Kairó az öbölháborút követően első alkalommal Líbiában vetette be külföldön katonáit. ${ }^{88}$ A líbiai Nemzeti Hadsereget többek között légi támogatással segítő Egyiptom Katart és Törökországot vádolja az ellentétes líbiai felek fegyverzésével és a konfliktus mélyítésével. Haftar tábornok 2019. áprilisi Tripoli elleni offenzívája megindítását követő héten Kairóban tárgyalt al-Szíszi elnökkel, aki továbbra is szilárd támogatásáról biztosíthatta a hadurat, annak ellenére, hogy hivatalos nyilatkozatában csupán annyit fogalmazott meg, hogy Egyiptom támogat minden olyan müveletet, amely a terror és szélsőséges csoportok felszámolására és a líbiai nép biztonságának garantálására irányul Líbia-szerte. ${ }^{89}$

Egyiptom számára Líbia stabilitása, területi egysége és az ország legalább keleti részének közrendi ellenőrzése biztonsági és gazdasági szempontokból is kiemelkedő fontosságú. A kelet-líbiai Kirenaika és az 1200 km-es közös határszakasz az elmúlt években az ember-, a kábítószer- és a fegyvercsempészet fellegvára, amely az egyiptomi feketepiac és korrupció éltető elemévé vált. E határszakaszon az „Iszlám Állam” és egyéb terrorszervezetek harcosai, valamint az erőszakos szalafista csoportok tagjai szabadon ,jönnek-mennek” a két ország között, ami biztonsági szempontból satuba szorítja Egyiptomot, egyik oldalon a polgárháborúba süllyedő Líbia, másik oldalon az iszlamista terror uralta Sínai-félsziget ölelésében. Haftar tábornok Kirenaikában és a határ mentén is közrendet és az iszlamista gócpontok felszámolását ígérte Egyiptomnak támogatásáért cserébe..$^{90} \mathrm{Az}$ egyiptomi-orosz közeledést és Haftar tábornok közös támogatását bizonyítja, hogy Egyiptom átengedte repülöterei használatát az orosz erők számára, így a líbiai-egyiptomi határtól 60 mérföldre fekvő légi bázist is igénybe vehetik az orosz gépek. ${ }^{91} \mathrm{~A}$ kelet-líbiai kormányzat megbízásából - a határ menti biztonsági problémákra válaszul és a határőrizet elősegítéséül - idén januárban fal építése kezdődött a határ vonalán egészen a sivatagos környezet jelentette természetes határszakaszig. ${ }^{92} \mathrm{Az}$ egyik legnagyobb határátkelö, Muszáid (mindössze $150 \mathrm{~km}$-re keletre Tobruktól) és Szallúm városait összekötő útvonalon az egyiptomi hadsereg is fokozott ellenőrzést gyakorol, amelynek költségeit nehezen bírja egyedül tovább viselni. E határ mentén nyitotta meg Egyiptom 2017-ben a Közel-Kelet legnagyobb katonai bázisát, ahol gyorsreagáló erőinek egy részét állomásoztatja. ${ }^{93}$

88 Daniela Musina: The Egyptian Security Complex and Lybia’s slow pace transition, [online], 2016. 10. 04. Forrás: Mediterraneanaffairs.com [2019. 02. 28.]

89 Patrick Wintour: Libya crisis: Egypt's Sisi backs Haftar assault on Tripoli, [online], 2019. 04. 14. Forrás: The Guardian [2019. 04. 23.]

90 Mustafa Fetouri: Does Libya have its own Al-Sisi in the making?, [online], 2019. 01. 24. Forrás: Middleeastmonitor. com [2019. 02. 28.]

91 Steven A. Cook: Putin is sneaking up on Europe from the South, [online], 2018. 08. 31. Forrás: Foreignpolicy.com [2019. 02. 28.]

92 2016-ban Algéria is bejelentette, hogy egy 350 km hosszú, 3 m magas falat húz a líbiai határ szakasza mentén.

93 Ahmed Megahid: Scepticism abounds over Egypt-Libya border wall, [online], 2019. 02. 03. Forrás: Thearabweekly.com [2019. 02. 28.] 
A közel 100 millió lakosú Egyiptom az öbölháborút követően nagyobb mértékben Líbiától vásárolta a kőolajat és a földgázt. Energetikai kiszolgáltatottságát a jövőben ugyan némileg csökkentheti az orosz hitellel és kivitelezéssel tervezett atomerőmü, valamint az elmúlt években felfedezett egyiptomi földgázlelőhely kiaknázása, de mind rövid, mind hoszszú távon a Líbiából olcsón importálható energiahordozó jelenti a megoldást a növekvő egyiptomi gazdaság számára. Az egyiptomi-líbiai jó kapcsolatok, és a líbiai belpolitikai stabilitás az egyiptomi vendégmunkások létét is meghatározza. Kaddáfi hatalomra kerülését követően számos egyiptomi orvos, tanár, hivatalnok vállalt munkát Líbiában. Továbbá, az egyiptomihoz nem hasonlítható kereseti lehetőség miatt Kaddáfi Líbiájában 2011-ben közel 1,5 millió egyiptomi vendégmunkás dolgozott, ${ }^{94}$ amelynek fele a polgárháború és az ISIS térnyerése miatt hazatért, így az általuk hazautalt pénzek elmaradása jelentős hiányt okoz az egyiptomi gazdaságnak, továbbá növeli az amúgy sem alacsony munkanélküliségi rátát. Az Iszlám Állam 2015-ben napvilágra került propagandavideójában 21 kopt keresztény egyiptomi lefejezését mutatta be. A közösség ellen irányuló atrocitások mára mindennaposak, amely ellen Egyiptom rendszeresen felemeli a szavát. Az ISIS támadását követően, 2015 februárjában Egyiptom katonailag is beavatkozott a válságba a terrorszervezet által uralt líbiai területek bombázásával.

Kairót Haftar tábornokra gyakorolt befolyása nélkülözhetetlenné teszi a líbiai egyeztetési fórumokon. A folyamatban békéltető, közvetítő szerepet viszont egyértelmü részrehajlása miatt nem vállalhat. Egyiptom az Európai Unió emberkereskedelmet és illegális migrációt feltartóztató müveleteiben is kiemelt partner.

Al-Szíszi hatalmon maradásának egyik kulcsa a líbiai biztonsági helyzet és egy Egyiptom számára kedvező politikai vezetés hatalomra segítése. A Kairót Líbiához kötő gazdasági és energetikai szálak erősítésén túlmenően al-Szíszi politikai érdeke a Muszlim Testvériség politikai térnyerésének és a különböző terrorszervezetek támadásainak megfékezése. A líbiai és az egyiptomi stabilitás és belbiztonság biztosítása révén al-Szíszi geopolitikai érdekei mentén tágíthatja külpolitikai mozgásterét.

\section{Katar, Szaúd-Arábia és az Egyesült Arab Emírségek}

Katar 2011-ben a NATO oldalán beavatkozó két arab állam egyikeként döbbentette meg az elemzőket. Doha döntése ugyanakkor erősen függött a nemzetközi közösség konszenzusától, ami 2011-ben Líbia esetében nem hiányzott. Ennek következménye volt az is, hogy az arab országok közül elsőként ismerte el a Nemzeti Átmeneti Tanácsot. Másrészt Katar nyugodt szívvel ajánlhatta fel a légierejének nagy részét képező hat Mirage 2000 vadászbombázót a feladatok végrehajtására. Ez a nyugodtság olyan biztonsági garanciákból fakadt, mint az Egyesült Államok légierejének al-Udeid bázisa, vagy az asz-Szajlija tábor, amely az amerikai fegyveres erők legnagyobb, anyaországon kívüli, előretolt bázisa. Emellett Franciaország és az Egyesült Királyság is támogatásáról biztosította a mindössze 1,6 milliós öböl menti államot. A katari részvétel a líbiai műveletekben nem merült ki a vadászbombázók bevetésében. Fegyverszállítmányok, anyagi segítség, kiképzés, sőt a rebellis

94 Giuseppe Dentice: Egypt's Security and Haftar: al- Sisi’s strategy in Libya, [online], 2017. 02. 02. Forrás: Ispionline.it [2019. 02.26.] 
kormánynak segítséget nyújtottak a kőolajeladásban is, a nemzetközi szankciók kivédése érdekében. A teljes körü katari segítségnyújtás célja az ország újrapozícionálása volt a nemzetközi porondon. Doha összekötő kapocsként, olyan szereplőként kívánta láttatni magát, aki a Nyugat és a megreformált iszlamista harcosok közötti teret sikerrel töltheti be. ${ }^{95}$

A Katarból érkező támogatás azonban nem minden arab ország szerint került megfelelö helyre. Doha ugyanis a Líbiában tevékenykedő iszlamista csoportokat, többek között a Muszlim Testvériséget részesítette elönyben. Ez pedig több ország, az Egyesült Arab Emírségek, Egyiptom, valamint Szaúd-Arábia érdekeit is sértette, akik úgy gondolták, hogy ezek a mozgalmak képesek a fennálló rezsimjeik legitimitásának megkérdőjelezésére. Katar, a líbiai belpolitikába való beavatkozáshoz való ragaszkodásával elvesztette a líbiai lakosság támogatását is. Mindeközben egyre erösödtek a hangok azzal kapcsolatban, hogy Doha nem kevesebbel, mint terrorista szervezetek támogatásával vádolható. ${ }^{96} \mathrm{Ez}$ a vád az ország Muszlim Testvériséggel ápolt jó viszonyából gyökerezik. ${ }^{97} \mathrm{E}$ mozgalom népszerüsítése nem talált meleg fogadtatásra a konzervatív iszlámfelfogást preferáló közel-keleti országok körében, különösen nem Szaúd-Arábiában. A növekvő ellenérzések 2017-ben érték el a tetőpontot, amikor Bahrein, Egyiptom, Jemen és Szaúd-Arábia közösen jelentette be, hogy megszakítják diplomáciai kapcsolataikat Katarral, valamint gazdasági szankciókat vezetnek be az országgal szemben. ${ }^{98}$ Katar a kereskedelmi kapcsolatainak diverzifikálásával sikeresen vészelte át ezt az időszakot, ${ }^{99}$ és folytathatta Szaúd-Arábia nemtetszését kiváltó politikáját, a Muszlim Testvériség és a GNA támogatását. ${ }^{100}$ Katar a Tripoli elleni offenzíva megkezdése után egy hatásos, Haftar tábornok vezette LNA elleni fegyverembargót követel, ${ }^{101}$ ezzel is tovább szítva a szaúdi királyság ellenszenvét.

Szaúd-Arábia ugyanis tulajdonképpen új szereplő a líbiai konfliktusban. A 2011-es eseményekbe a két ország közötti ellenséges viszony miatt nem szólt bele, és Rijád különösebb ellenérzés nélkül támogatta a felkelőket. Kaddáfi bukása a két ország közötti viszony rendezésének ígéretét is magában hordozta. 2012-ben meg is történt a diplomáciai kapcsolatok felvétele. Ezt gyorsan készpénzre váltotta Rijád a gazdasági kapcsolatok szintjén is, és 2013ban már meg is kötötte a líbiai kőolajiparba való befektetésről szóló szerződést. A líbiai biztonsági helyzet kedvezőtlen alakulása miatt azonban ez nem bizonyult jó üzletnek. Nemzetközi szinten jobban kamatozott a szaúdi szerepvállalás, hiszen nem kisebb cél lebegett Rijád szeme előtt, mint az Egyesült Államok szövetségének megnyerése. Ezt sikerült is minimális ráfordítással, különböző haditechnikai eszközök leszállításával biztosítani. ${ }^{102}$

95 David Roberts: Behind Qatar's Intervention In Libya, [online], 2011. 09. 28. Forrás: Foreignaffairs.com [2019. 04. 22.]

96 Qatar's Role in the Libyan Conflict: Who's on the Lists of Terrorists and Why, [online], 2017. 07. 14., Jamestown Foundation. Forrás: Refworld.org [2019. 05. 01.]

97 N. Rózsa Erzsébet et al.: Az Iszlám Állam kalifátusa, Osiris Kiadó - Külügyi és Külgazdasági Intézet, Budapest, 2016, 265. 0 .

98 JÁszberényi Sándor: Végső leszámolás a politikai iszlamizmussal, [online], 2017. 06. 06. Forrás: 24.hu [2019. 04. 30.]

99 Kristian Coates Ulrichsen: How Qatar Weathered the Gulf Crisis, [online], 2018. 06. 11. Forrás: Foreignaffairs.com [2019.04. 30.]

100 Ethan Chorin: Libya’s Perpetual Chaos, [online], 2019. 04. 19. Forrás: Foreignaffairs.com [2019. 04. 30.]

101 Qatar calls for arms embargo against Libya’s Haftar, [online], 2019. 04. 16. Forrás: Reuters.com [2019. 04. 30.]

102 Sherif Elashmawy: The foreign policies of Saudi Arabia and Qatar towards the Arab Uprisings, [online], 2014. Forrás: Ecpr.eu [2019. 04. 30.] 
Az aktívabb szaúdi szerepvállalást az Iszlám Állam 2016-os térnyerése hozta el. Ekkor a nemzetközi szereplők is bíztak Szaúd-Arábia regionális hatalmi státuszában, és abban, hogy ezt ki tudja használni a többi arab szereplő megzabolázására. Ennek megfelelően nagy remények füződtek a líbiai helyzet megoldásához is. ${ }^{103} \mathrm{~A}$ fentebb ismertetett katari politika azonban nem kedvezett a békéről szóló terveknek, és a tekintélyében sértett Rijád 2017-ben gazdasági blokádot vezetett be a kis öbölállam ellen.

Szaúd-Arábia talán egyik legsikeresebb fegyvere, amit Líbiában is bevetett a madkhali-szalafizmus, amely a Muszlim Testvériség ellenpólusaként létrejött konzervatív iszlám irányzat. A szaúdi teológusról elnevezett irányzat 2011 óta gyüjti a követőket Líbiában, és vélhetően ez az egyik leghatásosabb fegyver Rijád kezében a líbiai közhangulat befolyásolására. ${ }^{104}$ Haftar tábornok egyik legnagyobb támogatója márciusban meg is mutatta valódi befolyásának mértékét a 75 éves hadúr felett. Egyes források szerint, az április 4-én megindított offenzíva Tripoli ellen Haftar tábornok március 27-i rijádi látogatása során került szóba. Szaúd-Arábia, Egyiptom és az Egyesült Arab Emírségek is támogathatta az akciót, mind szóban, mind anyagilag. ${ }^{105}$

A 2011-es NATO-beavatkozás másik arab résztvevője az Egyesült Arab Emírségek (EAE) volt. ${ }^{106} \mathrm{~A}$ beavatkozás legnagyobb mozgatórugója az arab tavasz nyomán megingott közelkeleti hatalmi egyensúly volt, amely mind az Emírségeket, mind Szaúd-Arábiát arra sarkallta, hogy igyekezzen magához ragadni a kezdeményező szerepét. Az elöször csak humanitárius segítségnyújtást felajánló EAE, látva az aktívabb katari részvételt maga is felajánlott 6 darab F-16-os és 6 darab Mirage vadászbombázót a NATO-műveletbe. A 2011-es nemzetközi konszenzus létrejöttéhez nagyban hozzájárult, hogy Szaúd-Arábia, Katar és az EAE hathatósan képviselte a líbiai ügyet az arab és iszlám fórumokon. A kezdeti viszonylagos egyetértés után az Emírségek terrorizmusellenes és Muszlim Testvériség-ellenes politikájával vált ismertté. Ez vetett véget az öbölállamok közötti egyetértésnek, amely leginkább a Kaddáfi elleni mély ellenszenv gyümölcse volt, mint tágabb politikai együttmüködésé. A további együttműködés lehetősége végleg megpecsételődött 2014-ben, amikor Haftar tábornok megindította terrorellenes müveletét Bengázi ellen. Ekkor az Emírségek a tábornok által vezetett LNA mellé állt, mind logisztikailag, mind katonailag is támogatva - fóként légicsapásokkal - Haftar terrorellenes harcát. ${ }^{107} \mathrm{Az}$ Emírségek ezzel beállt az Egyiptom, majd később Oroszország alkotta csoportba, amely Haftar tábornokot támogatja. 2016ban az Emírségek odáig ment, hogy katonai bázist alakított ki Kelet-Líbiában az LNA által birtokolt területeken. A Bengázitól 105 km-re keletre elhelyezkedő ${ }^{108} \mathrm{Al}$-Khádim bázis már 2016-ban is több pilóta nélküli repülögépnek, valamint merev- és forgószárnyas

${ }^{103}$ Michel Cousins: Saudi Arabia set to announce Libya reconciliation talks in next few days, [online], 2016. 10. 25. Forrás: Libyaherald.com [2019. 05. 01.]

104 Addressing the Rise of Libya’s Madkhali-Salafis, ICG Report No. 200., [online], 2019. 04. 25. Forrás: Crisisgroup.org [2019.05.01.]

105 Saudi Arabia’s reckless prince fuels yet another civil war, [online], 2019. 04. 15. Forrás: Washingtonpost.com [2019. 05. 01.]

106 Ivo H. DAalder - James G. Stavridis: NATO's Victory in Libya, [online], 2012. 02. 02. Forrás: Foreignaffairs.com [2019. 04. 22.]

107 Saskia Van Genugten: The Gulf States: Channeling Regional Ambitions in Different Directions. In: Karim Mezran Arturo VARVELli (eds.): Foreign Actors In Libya's Crisis, [online], 2017, 42-46. o. Forrás: Ispionline.it [2019. 05. 27.]

108 Aidan Lewis: Covert Emirati support gave East Libyan air power key boost: U.N. report, [online], 2017. 06. 09. Forrás: Reuters.com [2019. 05. 27.] 
repülőeszköznek adott otthont, emellett az EAE fegyver és lőszerszállítással is hozzájárult az elhúzódó bengázi harcokhoz. ${ }^{109}$ 2017-ben, hogy ezt a tevékenységet legálisan is folytathassa, az Emírségek - a terrorizmus elleni harc fontosságára hivatkozva - a Líbiára kivetett fegyverembargó megszüntetését kérte, sikertelenül. Még ebben az évben megkezdődött az al-Khádim légibázis fejlesztése, amely az Emírségek továbbra is folyamatos támogatásának jeleként értékelhetö. ${ }^{110}$ 2017-ben egy ENSZ-jelentés is vizsgálta az Emírségek szerepét az LNA erőinek megerősödésében. A jelentés szerint az EAE légi eszközökön kívül szárazföldi haditechnikai eszközök szállításával is segítette 2014 és 2017 között Haftar tábornok erőit, mindezt a fegyverembargó ellenére. ${ }^{111}$

Habár az EAE elvben támogatja az ENSZ kezdeményezéseit egy békés rendezésre Líbiában, 2018 végéig nem csökkent, hanem növekedett az LNA külső támogatásának mértéke. ${ }^{112}$ Ez megmutatkozott akkor is, amikor Haftar tábornok dél-líbiai offenzíváját az Emírségek GNA tisztek megvesztegetésével kívánta meggyorsítani. ${ }^{113}$ Azonban az Emírségek is felmérte, hogy a biztos siker érdekében szorosabbra kell füznie a kapcsolatát a GNA-val is. Így 2018 végén már arról is lehetett hallani, hogy az Emírségek Tripoliban a nemzeti egységkormányhoz köthető személyekkel keresi a kapcsolatot. ${ }^{114}$ Mindemellett 2019-ben sem szünt meg az EAE és az LNA között fennálló kapcsolat, $s$ a fegyverszállítmányok továbbra is fejtörést okoznak mind a nemzetközi közösségnek, mind pedig a GNAnak. ${ }^{115}$ Az Emírségek hozzáállását a konfliktus jövőbeni alakulásához jól példázza, hogy 2019 májusában Abu Dhabi álláspontja szerint Tripoli extremista milíciák irányítása alatt állt, és Líbia hosszú távú stabilitásának érdekében a terrorizmus elleni küzdelem élvez prioritást. ${ }^{116}$

\section{Törökország}

A 2011-es líbiai események Törökországot is jelentősen sújtották, mindenekelőtt a gazdasági kapcsolatok területén. A Kaddáfi-korszak utolsó éveiben közel 20 ezer török vendégmunkás dolgozott Líbiában, ${ }^{117}$ továbbá több mint 15 milliárd dollár értékű török befektetés ${ }^{118}$ irányult elsősorban a líbiai építőiparba. A konfliktus során Ankara a puha eszközök alkalmazásával a felek közötti közvetítésre törekedett, ezért már a korai szakaszban felvette

109 Abdullah Ben IвRAhim: UAE sets up military base in east Libya - IHS, [online], 2016. 10. 28. Forrás: libyaobserver.ly [2019.05.27.]

110 UN team: UAE is developing its air base in eastern Libya, [online], 2018. 03. 02. Forrás: middleeastmonitor.com [2019. 05. 27.]

111 LEWIS: $i . m$.

112 Frederic Wehrey - Wolfram Lacher: The Wrong Way to Fix Libya, [online], 2018. 06. 19. Forrás: Foreignaffairs.com [2019. 05.27.]

113 Supported by the UAE, Haftar seeks to control south Libya, [online], 2019. 01. 02. Forrás: Middleeastmonitor.com [2019. 05. 27.]

114 Frederic Wehrey - Jalel Harchaoui: Is Libya Finally Ready for Peace?, [online], 2018. 11. 30. Forrás: Foreignaffairs. com [2019. 05. 27.]

115 Patrick Wintour: Libya crisis: UK officials anxious as blame is laid at doors of Gulf allies, [online], 2019. 04. 09. Forrás: The Guardian [2019. 05. 27.]

116 Aziz EL YAAкоubi: Haftar's ally UAE says ,extremist militias' control Libyan capital, [online], 2019. 05. 02. Forrás: Reuters.com [2019. 05. 27.]

117 Turkey says offered Gaddafi „guarantee” to quit Libya, [online], 2011. 06. 10. Forrás: Reuters.com [2019. 04. 20.]

118 TÁLAS: i. m., 81. o. 
a kapcsolatot az ellenzéki csoportokkal a tüzszünet elérésének reményében. Az ENSZ BTvel ellentétes véleményét és a francia fellépést elítélő álláspontját végül - valószínűsíthetően amerikai nyomásra - megváltoztatta, és csatlakozott a NATO műveleteihez.

Recep Tayyip Erdoğan török miniszterelnök, majd 2014 augusztusától elnök külpolitikájának egyik központi eleme a líbiai konfliktusban való szerepvállalás, jóllehet NATO-tagállamként, illetve a helyi orosz érdekekkel részben szembemenő álláspontja miatt csak bizonyos mértékig lehet hangsúlyos a jövőben. Az Igazság és Fejlődés Pártja (AKP) a Muszlim Testvériség egyik támogatója, amely meghatározza a líbiai - egyre inkább proxy - polgárháború nemzetközi szereplői közötti törésvonalat. Egyiptom első számú érdeke a Muszlim Testvériség háttérbe szorítása, tehát minél inkább akadályozni fogja, hogy a szomszédos Líbiában iszlamista vezetés győzedelmeskedjen. Hasonló állásponton áll, és ebből kifolyólag Haftar tábornok erőit támogatja Szaúd-Arábia, Kuvait és az Egyesült Arab Emírségek is. Mindeközben Katar Törökország szövetségese a líbiai színpadon. Haftar tábornok kelet-líbiai térnyerése óta Törökországot is a radikális, erőszakos iszlamista csoportok támogatásával vádolja, sőt a terrorizmus támogatása miatt 2014-ben felszólította a török és katari állampolgárokat Kelet-Líbia elhagyására. ${ }^{119}$

Ankara a Szarrádzs-kormány elkötelezett támogatója. Haftar tábornok több ízben vádolta meg Törökországot, hogy az ENSZ fegyverembargó ellenére löszerrel és kézifegyverekkel segíti Tripolit. 2018 decemberében két hajószállítmányt is elfogtak, amelyeken egyes források szerint 4,2 millió lőszer volt, amellyel Törökország a Haftarral szemben álló központi kormányerőket és milíciákat kívánta támogatni. ${ }^{120}$ Haftar vádja és az elfogott rakomány nagy port kavart. Az ENSZ líbiai missziója (UNSMIL) vizsgálatot indított, illetve Szarrádzs elnök és Mevlüt Çavuşoğlu török külügyminiszter is kénytelen volt közös nyomozás megindításáról nyilatkozni.

A líbiai konszolidáció folyamatában Törökországot is megkerülhetetlen szereplőnek tekinthetjük. A 2018. novemberi palermói konferencián nyilvánvalóvá vált az ország határozott külpolitikai elképzelése, hiszen miután a konferencián Haftar tábornok is megjelent a török delegáció „mély csalódásának” adott hangot ${ }^{121}$ és elhagyta a rendezvényt. A konferenciát megelőző hetekben a török védelmi miniszter tett látogatást Tripoliban, majd Szarrádzs elnök látogatott Ankarába Erdoğan elnökhöz. ${ }^{122}$ A két ország között immár rendszeresek a légi járatok, továbbá felélénkültek a gazdasági kapcsolatok is: 18 milliárd dollár értékű a folyamatban levő gazdasági együttműködés, és további 250 milliárd dollár értékü infrastrukturális beruházás teljesítése is tervben van. ${ }^{123}$

Törökország aggodalmát fejezte ki Haftar Líbiai Nemzeti Hadseregének idén áprilisban Tripoli ellen indított offenzívája miatt. A polgárháborús viszonyok elmélyülése lehetetlenné teszi a líbiai stabilitás elérését és a gazdasági együttmüködések fenntartását. A török gazdaság és külpolitika orosz kapcsolatai miatt kérdéses ugyanakkor, hogy mekkora mér-

\footnotetext{
119 Lorenzo Sigillino: Libya: the theatre of Turkish isolation, [online], 2015. 05. 21. Forrás: Mediterraneanaffairs.com [2019. 04. 19.]

120 Haftar accuses Turkey of violating arms embargo on Libya, [online], 2018. 12. 21. Forrás: Thearabweekly.com [2019. 04. 20.]

121 Conte e Salamè: "Vertice sulla Libia un successo". Ma la Turchia abbandona i lavori in protesta, [online], 2018. 11. 13. Forrás: Lastampa.it [2019. 04. 20.]

122 Haftar displeasure over Qatar, Turkey on display at Palermo, [online], 2016. 11. 14. Forrás: Alarabiya.net [2019. 04. 20.]

123 Turkey raises concern over tension in Libya, [online], 2019. 04. 08. Forrás: Yenisafak.com [2019. 04. 20.]
} 
tékben fogja tovább vinni Ankara saját, az iszlamista kormányt támogató terveit, és milyen mértékben fog a gazdasági-politikai pragmatizmus felé elmozdulni.

\section{Konklúzió}

Annak ellenére, hogy a nemzetközi szereplök a szavak szintjén többnyire támogatják Líbia területi egységének és politikai stabilitásának szükségességét, az egymásétól jelentősen eltérő politikai, gazdasági és biztonságpolitikai érdekek miatt valójában keveset tesznek ennek megvalósítása érdekében. Az egymással szemben álló hatalmi központok nemzetközi szereplők általi támogatása - az európai biztonságot jelentős mértékben veszélyeztető és a szíriai konfliktushoz hasonló - akár évekig elhúzódó proxyháborúhoz is vezethet.

Az Egyesült Államok - Donald Trump bejelentése szerint - nem kíván aktívan részt venni a líbiai stabilizáció és nemzetépítés folyamatában, a Trump-adminisztráció nem kíván amerikai katonákat küldeni Líbiába, ${ }^{124}$ felvállalva, hogy a limitált amerikai jelenlét miatt Washington nem fogja tudni befolyásolni, milyen lesz Líbia jövője. Az Egyesült Államok aktív jelenlétének „hiányában” más nagyhatalmak és középhatalmak elött nyílt meg a lehetőség, hogy saját érdekeik mentén puha és kemény eszközeikkel alakítsák a líbiai helyzetet. A nemzetközi szereplők között azonban jelentős érdekkülönbségek vannak, így más líbiai hatalmi központokat támogatnak, hozzájárulva a félanarchikus, nem egységes Líbia fenntartásához.

A kínai külpolitika pragmatikus voltának kiváló példáját láthatjuk a líbiai válság elemzése során. A 2011-es beavatkozás után az Egyesült Âllamok és Európa „kihátrálása” légüres teret hozott létre, ezt a hatalmi vákuumot Kína is egyre fokozott erőbefektetéssel próbálja betölteni. Geopolitikai érdekei megkövetelik, hogy a jövőben is puhán, de határozottan beavatkozzon a líbiai belpolitikába.

Oroszország nem csupán Haftart, hanem Tripolit is támogatja, sőt, a miszrátai milíciákkal is kapcsolatot tart fenn, hiszen Haftar jövőbeli szerepe nem egyértelmü, így Moszkva nem teheti meg, hogy egyedül ezt a hatalmi központot támogassa. A legfontosabb érintett felekkel való párhuzamos kapcsolattartás lehetővé teszi számára, hogy a felek közti közvetítő szerepében tüntesse fel magát, ami az EU-val való tárgyalásai során is alku tárgyát képezheti. Jelenléte hozzájárulhat az orosz erőkivetítési képességek megerősítéséhez Nyugat-Európa közelében.

Az Európai Unió tagállamai közül hagyományosan Olaszország, és az arab tavaszra gyorsabban és határozottabban reagáló Franciaország próbálja leginkább politikailag, puha és kemény eszközök használatával befolyásolni a jövő Líbiáját. Mindkét európai állam - egymással rivalizálva - vezető szerepet kíván betölteni a polgárháború utáni rendezésben. Ezzel párhuzamosan Németország legnagyobb donorországként egyértelműen puha eszközökkel, gazdasági segélyekkel él inkább. A korábban külpolitikailag megkerülhetetlen Egyesült Királyság a brexit megvalósításával foglalja le saját erőforrásait, így líbiai szerepe háttérbe szorult, ezért ezt a tanulmányban nem is vizsgáltuk önállóan.

124 Glenn Thrush: No U.S. Military Role in Libya, Trump Says, Rejecting Italy's Pleas, [online], 2017. 04. 20. Forrás: Nytimes.com [2019. 02. 10.] 
Haftar nagyon határozott támogatásával Egyiptom alkalmazza a legegyértelmübben a kemény eszközöket a líbiai helyzet saját érdekei mentén történő alakítására. Kairó mellett a regionális szereplőknél meg kell említeni Szaúd-Arábiát, Katart, az Egyesült Arab Emírségeket és Törökországot is, hiszen regionális befolyásuk növelése érdekében mindegyikük kemény eszközöket is alkalmaz Líbiában.

A szétzilálódott Líbiát a nemzetközi szereplök saját érdekeik mentén kívánják befolyásolni, ezzel ugyanakkor egyre távolabb kerül Líbia stabilizálása. Napjainkra az országban a nagyhatalmak, a regionális hatalmak és az Európai Unió tagállamai között is érdekellentétek feszülnek, amit Khalífa Haftar 2019 áprilisában indított offenzívája tovább súlyosbított (elég csak az olasz-francia kapcsolatok további romlására gondolni). A Tripoli ellen indított támadást két olyan ország is szinte nyíltan támogatja - Oroszország és Franciaország - amelyek az ENSZ BT állandó tagjai, bár ezzel párhuzamosan elismerik a Szarrádzs-kormányt is. Az Egyesült Államok - Trump Haftarral folytatott telefonbeszélgetésétől eltekintve -, Olaszország és Egyesült Királyság következetesen a helyzet politikai rendezése mellett áll. Erre azonban nem kerülhet sor a nagyhatalmak megegyezése és a líbiai főbb politikai és katonai erök közötti közvetítés nélkül.

\section{FELHASZNÁLT IRODALOM}

300 Russian mercenaries fighting for warlord Khalifa Haftar in Libya, western news reports say, [online], 2019. 03. 04. Forrás: Libyaobserver.ly [2019. 04. 23.]

A Biztonsági Tanács 1973 (2011) számú határozata a Líbia fölötti repüléstilalmi övezet létesítéséről és a civil lakosság védelmére minden szükséges intézkedés megtételéről, [online], 2011. 03. 18. Forrás: Grotius.hu [2019. 04. 22.]

Addressing the Rise of Libya’s Madkhali-Salafis, ICG Report No. 200., [online], 2019. 04. 25. Forrás: Crisisgroup.org [2019. 05. 01.]

AL-Atrush, Samer - JACOBS, Jennifer - TALEy, Margaret: Trump Backed Libyan Strongman's Attack on Tripoli, U.S. Officials Say, [online], 2019. 04. 24. Forrás: Bloomberg.com [2019. 04. 25.]

AL-Ghwell, Hafed: The United States Should Not Get Involved in Libya’s Civil War, [online], 2018. 11. 14. Forrás: Atlanticcouncil.org [2019. 02. 27.]

Alharathly, Safa: Libya joins China’s Belt and Road Initiative, [online], 2018. 07. 13. Forrás: Libyaobserver. ly [2019. 02.21.]

Armed men crossing from Libya alleged to be French spies, [online], 2019. 04. 23. Forrás: Aljazeera.com [2019. 04. 30.]

BACHIR, Malek: Les «trois politiques» de la France en Libye, [online], 2017. 07. 25. Forrás: Middleeasteye.net [2019. 04. 22.]

Becker, Jo - Schmidt, Eric: As Trump Wavers on Libya, an ISIS Haven, Russia Presses On, [online], 2018. 02. 07. Forrás: Nytimes.com [2019. 02. 16.]

Ben IвrAhim, Abdullah: UAE sets up military base in east Libya - IHS, [online], 2016. 10. 28. Forrás: Libyaobserver.ly [2019. 05. 27.]

Benghazi: US Navy SEALs capture man suspected over fatal attack on diplomatic post in Libya, [online], 2017. 10. 31. Forrás: ABC.net.au [2019. 03. 04.]

Binnie, Jeremy: LNA advances across southwest Libya. Jane’s Defence Weekly, 56. évf. 2019/11

Chorin, Ethan: Libya’s Perpetual Chaos, [online], 2019. 04. 19. Forrás: Foreignaffairs.com [2019. 04. 30.]

Chossudovsky, Michel: When War Games Go Live: "Staging" a "Humanitarian War" against "SOUTHLAND”, [online], 2011. 04. 16. Forrás: Globalresearch.ca [2019. 04. 22.] 
Conte e Salamè: "Vertice sulla Libia un successo". Ma la Turchia abbandona i lavori in protesta, [online], 2018. 11. 13. Forrás: Lastampa.it [2019. 04. 20.]

Conte: Italia, Russia e Tunisia respingono una soluzione militare in Libia, [online], 2019. 05. 02. Forrás: Luiss. it [2019. 05. 12.]

Cook, Steven A.: Putin is sneaking up on Europe from the South, [online], 2018. 08. 31. Forrás: Foreignpolicy.com [2019. 02. 28.]

Cousins, Michael: Germany continues to lead foreign financial support for Libya, [online], 2018. 01. 03. Forrás: Libyaherald.com [2019. 04. 01.]

Cousins, Michel: Saudi Arabia set to announce Libya reconciliation talks in next few days, [online], 2016. 10. 25. Forrás: Libyaherald.com [2019. 05. 01.]

Cuscito, Giorgio: La Cina tornerà in Libia, [online], 2018. 07. 27. Forrás: Limesonline.com [2019. 02. 21.]

DAALDER, Ivo H. - StAvridis, James G.: NATO’s Victory in Libya, [online], 2012. 02. 02. Forrás: Foreignaffairs.com [2019. 04. 22.]

DAvid, Dominique: Libye: intervenir, encore?, [online], 2016. 04. 12. Forrás: Ifri.org [2019. 04. 22.]

Dentice, Giuseppe: Egypt's Security and Haftar: al- Sisi’s strategy in Libya, [online], 2017. 02. 02. Forrás: Ispionline.it [2019. 02. 26.]

Dichiarazione congiunta del Ministro dell'Europa e degli affari esteri, Jean-Yves Le Drian, e del Ministro degli affari esteri e della cooperazione internazionale, Enzo Moavero Milanesi (13 maggio 2019), [online], 2019. 05. 13. Forrás: Esteri.it [2019. 05. 15.]

EL YAakoubi, Aziz: Haftar's ally UAE says ,extremist militias' control Libyan capital, [online], 2019.05.02. Forrás: Reuters.com [2019. 05. 27.]

Elashmawy, Sherif: The foreign policies of Saudi Arabia and Qatar towards the Arab Uprisings, [online], 2014. Forrás: Ecpr.eu [2019. 04. 30.]

Engelberth István: „Chinafrica”? - Afrika a XXI. század küszöbén, EU Working Papers 2009/3. 41-52. o.

Fetouri, Mustafa Dr.: Does Libya have its own Al-Sisi in the making?, [online], 2019. 01. 24. Forrás:

Middleeastmonitor.com [2019. 02. 28.]

Fishman, Ben: United States: Reluctant Engagement. In: Mezran, Karim - Varvelli, Arturo (eds.): Foreign Actors in Libya's Crisis, Atlantic Council, Edizione LediPublishing, Milano, 2017, 91-111. o.

France, committed to assisting the countries of the Sahel, [online], 2015. 11. 25. Forrás: Delegfrance.org [2019. 04. 30.]

French special forces withdraw from Libya’s Benghazi, [online], 2016. 08. 11. Forrás: Worldbulletin.net [2019. 04. 22.]

Gerstein, Josh - Lin, Jeremy C. F.: Why these 7 countries are listed on Trump's travel ban, [online], 2018. 06. 26. Forrás: Politico.com, [2019. 02. 13.]

Haftar accuses Turkey of violating arms embargo on Libya, [online], 2018. 12. 21. Forrás: Thearabweekly.com [2019. 04. 20.]

Haftar displeasure over Qatar, Turkey on display at Palermo, [online], 2016. 11. 14. Forrás: Alarabiya.net [2019. 04. 20.]

Hawthorne, Amy - Miller, Andrew: Worse Than Mubarak, [online], 2019. 02. 27. Forrás: Foreignpolicy. com [2019. 02. 28.]

Highlights of Xi's speech at China-Arab forum, [online], 2018. 07. 10. Forrás: Chinadaily.com.cn [2019. 02. 21.]

Jacobs, Andrew - Perlez, Jane: U.S. Wary of Its New Neighbor in Djibouti: A Chinese Naval Base, [online], 2017. 02. 25. Forrás: Nytimes.com [2019. 02. 20.]

JÁszBeréNyi Sándor: Végső leszámolás a politikai iszlamizmussal, [online], 2017. 06. 06. Forrás: 24.hu [2019. 04. 30.]

Junbo, Jian - MÉndez, Álvaro: Change and Continuity in Chinese Foreign Policy: China’s Engagement in the Libyan Civil War as a Case Study, LSE Global South Unit Working Paper Series No. 5/2015, [online]. Forrás: lse.ac.uk [2019. 02. 21.]

Kozhanov, Nikolay: Moscow's Presence in Libya Is a New Challenge for the West, [online], 2017. 05. 30. Forrás: Chathamhouse.org [2019. 02. 12.] 
L'opération Harmattan, [online], 2011. 09. 27. Forrás: Defense.gouv.fr [2019. 04. 22.]

LAMPERTI, Lorenzo: Cina pronta a investire in Libia. Così Pechino può salvare Africa (ed Europa), [online], 2019. 02. 18. Forrás: Affaritaliani.it [2019. 02. 21.]

Legge 6 febbraio 2009, n. 7. Ratifica ed esecuzione del Trattato di amicizia, partenariato e cooperazione tra la Repubblica italiana e la Grande Giamahiria araba libica popolare socialista, fatto a Bengasi il 30 agosto 2008, Gazzetta Ufficiale, No. 40., [online], 2009. 02. 18. Forrás: Parlamento.it [2019. 04. 23.]

LEwIS, Aidan: Covert Emirati support gave East Libyan air power key boost: U.N. report, [online], 2017. 06. 09. Forrás: Reuters.com [2019. 05. 27.]

LEwIS, Aidan: Separate banknotes symbols of Libyan disunity, financial, [online], 2016. 06. 03. Forrás: Reuters.com [2019. 02. 10.]

Libye - Relations bilatérales, [online]. Forrás: Diplomatie.gouv.fr [2019. 04. 22.]

Libya: Examination of intervention and collapse and the UK's future policy options, [online], 2016. 09. 14., House of Commons Foreign Affairs Committee. Forrás: Parliament.uk [2019. 04. 22.]

Libia, Conte e Salvini: „No a interventi militari”. Il ministro dell'Interno: „Cè dietro qualcuno”. E attacca la Francia, [online], 2018. 09. 03. Forrás: Repubblica.it [2019. 04. 23.]

Libia, Haftar a Roma per incontrare Conte. L'Italia sempre più vicina al generale, [online], 2018. 12. 05. Forrás: Ilmessaggero.it [2019. 03. 02.]

Lindström, Madelene - ZetTerLund, Kristina: Setting the Stage for the Military Intervention in Libya, [online], 2012. 10., 17. o. Forrás: Foi.se [2019. 04. 22.]

MaLsin, Jared: Libyan Warlord Embraced by Foreign Leaders as a Key to Peace, [online], 2018. 12. 03. Forrás: Wsj.com [2019. 03. 08.]

Mare Nostrum, [online]. Forrás: Difesa.it [2019. 04. 23.]

MARSAI Viktor: A líbiai válság elmúlt két és fél éve európai szemszögből, [online], Nemzet és Biztonság, 7. évf., 2014/3, 82-104. o.

MARSAI Viktor: A migrációs diskurzus margójára III. - A líbiai válság az európai migráció tükrében, [online], Nemzet és Biztonság, 10. évf., 2017/1, 110-131. o.

MARsAi Viktor: Líbia agóniája. In: MolnÁr Anna - Komlósi Orsolya (szerk.): Az Európai Unió mediterrán térséggel összefüggő kapcsolata. Párbeszéd és konfliktusok, [online], Dialóg Campus Kiadó, Budapest, 2019, 77-94. o.

Megahid, Ahmed: Scepticism abounds over Egypt-Libya border wall, [online], 2019. 02. 03. Forrás: Thearabweekly.com [2019. 02. 28.]

Migranti: accordo Italia-Libia, il testo del memorandum, [online], 2017. 02. 02. Forrás: Repubblica.it [2019. 04. 22.]

MolnÁr Anna: Az EUNAVFOR MED Sophia művelet. In: MolnÁr Anna - KomLósı Orsolya (szerk.): Az Európai Unió mediterrán térséggel összefüggő kapcsolata. Párbeszéd és konfliktusok, [online], Dialóg Campus Kiadó, Budapest, 2019, 95-123. o.

MolnÁr Anna: Olaszország és Líbia kapcsolata a 2011-es polgárháború tükrében, [online], Kül-Világ, 8. évf., 2011/4, 1-26. o. [2019. 05. 24.]

Musina, Daniela: The Egyptian Security Complex and Lybia's slow pace transition, [online], 2016. 10. 04. Forrás: Mediterraneanaffairs.com [2019. 02. 28.]

N. Rózsa Erzsébet et al.: Az Iszlám Állam kalifátusa, Osiris Kiadó - Külügyi és Külgazdasági Intézet, Budapest, 2016

NATO and Libya (Archived), [online], 2015. 11. 09. Forrás: Nato.int [2019. 04. 22.]

Neuen, Fabian: Germany’s nightmare: Responding to the Libyan Crisis, [online], 2011. 09. 28. Forrás: Fairobserver.com [2019. 03. 12.]

Nichols, Michelle: U.S., Russia say cannot support a U.N. call for Libya truce: diplomats, [online], 2019. 05. 19. Forrás: Reuters.com [2019. 05. 23.]

NYE, Joseph S.: Soft Power: The Means To Success In World Politics, PublicAffairs, New York, 2004

Operazione Ippocrate, Schieramento di un ospedale da campo in Libia, [online]. Forrás: Difesa.it [2019. 04. 23.]

PARfitt, Tom: Gadafy offers Russia a naval base in Libya, [online], 2008. 11. 01. Forrás: The Guardian [2019. 02. 10.] 
Pigman, Lincoln - Orton, Kyle: Inside Putin’s Libyan Power Play, [online], 2017. 09. 14. Forrás:

Foreignpolicy.com [2019. 02. 10.]

Pinotti: «L'Onu ritorna in Libia, più controlli su chi parte», [online], 2017. 04. 29. Forrás: Partitodemocratico.it [2019. 04. 22.]

Presidential Proclamation Enhancing Vetting Capabilities and Processes for Detecting Attempted Entry Into the United States by Terrorists or Other Public-Safety Threats, [online], 2017. 09. 24. Forrás: Whitehouse. gov [2019. 03. 09.]

PuszTAI, Wolfgang: The Haftar-Russia Link and the Military Plan of the LNA, [online], 2017. 02. 02. Forrás: Ispionline.it [2019. 02. 10.]

Qatar calls for arms embargo against Libya’s Haftar, [online], 2019. 04. 16. Forrás: Reuters.com [2019. 04. 30.]

Qatar's Role in the Libyan Conflict: Who's on the Lists of Terrorists and Why, [online], 2017. 07. 14. Jamestown Foundation. Forrás: Refworld.org [2019. 05. 01.]

RAME, Sergio: Forze speciali italiane in Libia: ecco il documento top secret, [online], 2016. 08. 10. Forrás: Ilgiornale.it [2017. 09. 22.]

Relazioni economiche Italia-Libia, [online]. Forrás: Esteri.it [2019. 04. 22.]

Roberts, David: Behind Qatar's Intervention In Libya, [online], 2011. 09. 28. Forrás: Foreignaffairs.com [2019. 04. 22.]

Russia disowns Libya’s General Haftar, [online], 2019. 04. 06. Forrás: Middleeastmonitor.com [2019. 04. 23.]

Saudi Arabia's reckless prince fuels yet another civil war, [online], 2019. 04. 15. Forrás: Washingtonpost.com [2019. 05. 01.]

SigiLLino, Lorenzo: Libya: the theatre of Turkish isolation, [online], 2015. 05. 21. Forrás:

Mediterraneanaffairs.com [2019. 04. 19.] DOI: https://doi.org/10.15448/1980-3710.2014.2.20103

Supported by the UAE, Haftar seeks to control south Libya, [online], 2019. 01. 02. Forrás: Middleeastmonitor. com [2019. 05. 27.]

SzAKáLi Máté: Szafarin a Sárkány: Kína befektetései Afrikában, [online], Külügyi Szemle, 14. évf., 2015/3, 75-95. o.

TÁLAs Péter et al: A líbiai beavatkozás motivációi és nemzetközi megítélése, Nemzet és Biztonság, 4. évf., 2011/3, 65-84. o.

TAYLOR, Paul: France’s double game in Libya, [online], 2019. 04. 17. Forrás: Politico.eu [2019. 04. 30.]

The Berlin Pulse 2017 - German Foreign Policy in Perspective, [online], 2017/11. Forrás: Koerber-stiftung.de [2019. 03. 23.]

Thrush, Glenn: No U.S. Military Role in Libya, Trump Says, Rejecting Italy's Pleas, [online], 2017. 04. 20. Forrás: Nytimes.com [2019. 02. 10.]

TIDEY, Alice: Libya's UN-backed government suspends cooperation with France, accuses it of backing rebel forces, [online], 2019. 04. 19. Forrás: Euronews.com [2019. 04. 30.]

Tierney, Dominic: The Legacy of Obama’s 'Worst Mistake', [online], 2016. 04. 15. Forrás: Theatlantic.com [2019. 03. 09.]

Turkey raises concern over tension in Libya, [online], 2019. 04. 08. Forrás: Yenisafak.com [2019. 04. 20.]

Turkey says offered Gaddafi „guarantee” to quit Libya, [online], 2011. 06. 10. Forrás: Reuters.com [2019. 04. 20.]

U.S. Energy Information Administration: U.S. Import from Libya of Crude Oil and Petroleum Products, [online]. Forrás: Eia.gov [2019. 03. 07.]

ULRICHSEN, Kristian Coates: How Qatar Weathered the Gulf Crisis, [online], 2018. 06. 11. Forrás: Foreignaffairs.com [2019.04. 30.]

UN team: UAE is developing its air base in eastern Libya, [online], 2018. 03. 02. Forrás: Middleeastmonitor. com [2019. 05. 27.]

Van Genugten, Saskia: The Gulf States: Channeling Regional Ambitions in Different Directions. In: Mezran, Karim - Varvelli, Arturo (eds.): Foreign Actors In Libya’s Crisis, [online], 2017, 42-46. o. Forrás: Ispionline.it [2019. 05. 27.]

VARvelLI, Arturo: Libia: conferenza di Palermo, il bilancio dell'Italia, [online], 2018. 12. 12. Forrás: Affarinternazionali.it [2019. 04. 23.] 
Video shows Egypt soldiers fighting in Libya’s Derna, [online], 2019. 02. 19. Forrás: Middleeastmonitor.com [2019. 02. 27.]

Wehrey, Frederic - Harchaoui, Jalel: Is Libya Finally Ready for Peace?, [online], 2018. 11. 30. Forrás: Foreignaffairs.com [2019. 05. 27.]

Wehrey, Frederic - Lacher, Wolfram: The Wrong Way to Fix Libya, [online], 2018. 06. 19. Forrás: Foreignaffairs.com [2019. 05. 27.]

Weitershausen, Inez von - Schäfer, David - Wessels, Wolfgang: A 'Primus Inter Pares' in EU Foreign Policy? - German Leadership in the European Council during the Libyan and Ukrainian Crises. German Politics. DOI: 10.1080/09644008.2019.1583328.

WEMAËRE, Alcyone: L'intervention militaire française au nord du Tchad pose question, [online], 2019. 02. 07. Forrás: France24.com [2019. 04. 22.]

Where does France import Crude Petroleum from?, [online], 2017. Forrás: Mit.edu [2019. 04. 30.]

Wintour, Patrick: Libya crisis: Egypt's Sisi backs Haftar assault on Tripoli, [online], 2019. 04. 14. Forrás: The Guardian [2019. 04. 23.]

WINTOuR, Patrick: Libya crisis: UK officials anxious as blame is laid at doors of Gulf allies, [online], 2019. 04. 09. Forrás: The Guardian [2019. 05. 27.] 